\title{
Preliminary evaluation of the potential of tree-ring cellulose content as a novel supplementary proxy in dendroclimatology
}

\author{
Malin M. Ziehmer ${ }^{1,2}$, Kurt Nicolussi ${ }^{3}$, Christian Schlüchter ${ }^{2,4}$, and Markus Leuenberger ${ }^{1,2}$ \\ ${ }^{1}$ Climate and Environmental Physics, Physics Institute, University of Bern, 3012 Bern, Switzerland \\ ${ }^{2}$ Oeschger Center for Climate Change Research, University of Bern, 3012 Bern, Switzerland \\ ${ }^{3}$ Institute of Geography, University of Innsbruck, 6020 Innsbruck, Austria \\ ${ }^{4}$ Institute of Geological Sciences, University of Bern, 3012 Bern, Switzerland
}

Correspondence: Malin M. Ziehmer (ziehmer@climate.unibe.ch)

Received: 30 March 2017 - Discussion started: 10 April 2017

Revised: 22 November 2017 - Accepted: 21 December 2017 - Published: 21 February 2018

\begin{abstract}
Cellulose content (CC (\%)) in tree rings is usually utilised as a tool to control the quality of the $\alpha$-cellulose extraction from tree rings in the preparation of stable-isotope analysis in wooden tissues. Reported amounts of CC (\%) are often limited to mean values per tree. For the first time, CC (\%) series from two high-Alpine species, Larix decidua Mill. (European Larch, LADE) and Pinus cembra L. (Swiss stone pine, PICE) are investigated in modern wood samples and Holocene wood remains from the Early and midHolocene. Modern CC (\%) series reveal a species-specific low-frequency trend independent of their sampling site over the past 150 years. Climate-cellulose relationships illustrate the ability of $\mathrm{CC}(\%)$ to record temperature in both species but for slightly different periods within the growing season.

The Holocene $\mathrm{CC}(\%)$ series illustrate diverging lowfrequency trends in both species, independent of sampling site characteristics (latitude, longitude and elevation). Moreover, potential age trends are not apparent in the two coniferous species. The arithmetic mean of $\mathrm{CC}(\%)$ series in the Early and mid-Holocene indicate low $\mathrm{CC}(\%)$ succeeding cold events. In conclusion, $\mathrm{CC}(\%)$ in tree rings show high potential to be established as novel supplementary proxy in dendroclimatology.
\end{abstract}

\section{Introduction}

Highly resolved proxy records from the tree-ring archive contribute significantly to reconstructing and understanding past climate variability on versatile temporal and spatial scales (Büntgen et al., 2011; Esper et al., 2002; Mann et al., 1998). The annually resolved and calendar-dated tree-ring records are particularly useful in disentangling natural climate variability from the anthropogenic imprint on the global climate and its impact on the climate system, which enables the improvement of models in view of projecting future climate change (Keel et al., 2016; Keller et al., 2017).

Most dendroclimatological reconstructions are based on tree-ring width (TRW) and maximum latewood density (MXD) records (Büntgen et al., 2006; Ljungqvist et al., 2016; Trouet et al., 2009). However, the determination of stableisotope ratios of carbon $\left(\delta^{13} \mathrm{C}\right)$, oxygen $\left(\delta^{18} \mathrm{O}\right)$ and hydrogen $(\delta \mathrm{D})$ isotopes in tree components and their ability to reconstruct past climate has gradually opened up a new field of dendroclimatology over the past four decades (Frank et al., 2015; Leuenberger, 1998; McCarroll and Loader, 2004; Treydte et al., 2006). In addition, the potential of stableisotope records in tree rings has been increased by improvements in both sample preparation and measurement techniques (Boettger et al., 2007; Filot et al., 2006; Laumer et al., 2009; Loader et al., 2015). Even though the isotopic composition has been determined in various components of a tree, e.g. bulk wood samples, leaves, methoxyl groups of lignin and leaf waxes (Anhäuser et al., 2017; Borella et al., 1999; Kahmen et al., 2011; Kimak et al., 2015), the most preferred component is $\alpha$-cellulose extracted from tree rings (Borella et al., 1998, 1999; Loader et al., 2003, 2013; McCarroll and Loader, 2004; Treydte et al., 2007). A major advantage of using $\alpha$-cellulose in isotope research is the extraction of one single chemical component of a tree ring. Thereby it allows 
researchers to circumvent the biases that potentially result from a changing composition (i.e. in the cellulose / lignin ratio) when analysing bulk wood since different components exhibit significantly different isotope compositions (Borella et al., 1998, 1999).

The $\alpha$-cellulose is the dominant component in tree rings and its extraction follows a standardised procedure (Boettger et al., 2007). The woody annual growth layers of trees, i.e. the tree rings, are composed of lignin (phenolic polymer), hemicellulose (heterogenous polysaccharides) and cellulose $(\beta-1,4$ glucan) in a ratio of $1: 1: 2$ (Freudenberg, 1965; Hu et al., 1999). Thereof, the part of cellulosic material which is insoluble in a $17 \%$ sodium hydroxide $(\mathrm{NaOH})$ solution is defined as $\alpha$-cellulose (Burton and Rasch, 1931; Cross and Bevan, 1912). The various tree-ring components are known to differ in their isotopic composition, whereas $\alpha$-cellulose is the most stable component, as the polymer is of long-term stability (Boettger et al., 2007; Leavitt and Danzer, 1993; McCarroll and Loader, 2004).

The quantity of the $\alpha$-cellulose content (hereinafter referred to as $\mathrm{CC}(\%)$ ), generally calculated from the dry weight and the $\alpha$-cellulose weight of a wood sample, is usually determined and used as a tool to test the quality of the cellulose extraction and the purity of the cellulose (Burton and Rasch, 1931).

However, variations in the amount of $\alpha$-cellulose and the determined $\mathrm{CC}(\%)$ (also cellulose yield; used rather simultaneously in the literature) are scarcely mentioned in dendroclimatological literature. Merely a few publications provide numbers on the mean extracted CC (\%) (Cullen and Macfarlane, 2005; Gaudinski et al., 2005; Leavitt and Danzer, 1993; Loader et al., 1997). While reported results on the CC (\%) are scarce in the literature, the importance of the $\mathrm{CC}(\%) \mathrm{cal}-$ culation as a tool for the determination of degradation state in subfossil wood is addressed within several studies (Brenninkmeijer, 1983; Loader et al., 2003 and references therein; Schleser et al., 1999).

Schleser et al. (1999) point out that the determination of isotopic ratios in cellulose from woody plant tissues often assumes constancy in the CC $(\%)$, which may hold true for modern samples from living trees. However, samples from subfossil or fossil wood have presumably experienced degradation processes with potential influence on the $\mathrm{CC}(\%)$. The artificial degradation of samples revealed a discrimination of $\delta^{13} \mathrm{C}$ values up to $0.3 \%$ with decreasing $\mathrm{CC}(\%)$ where the change in degradation behaviour over time splits into initially increased degradation of cellulose with a strong depletion in $\delta^{13} \mathrm{C}$, followed by an inverse effect comprising an enrichment in $\delta^{13} \mathrm{C}$ with advancing degradation (Schleser et al., 1999).

Loader et al. (2003) discusses the use of whole wood versus $\alpha$-cellulose in subfossil tree samples as the various wood components (lignin, hemicelluloses, cellulose) experience variable degrees of decomposition, changing the ratio of the individual components within a tree ring. The polysac- charide components, i.e. cellulose and hemicelluloses, decompose more rapidly than lignin, which leads to an altered ratio of cellulose and lignin in whole wood samples, which in turn modifies the isotopic composition of whole wood samples (Borella et al., 1998; Loader et al., 2003; Schleser et al., 1999). Therefore, cellulose is the preferred wood component in subfossil wood studies; however, the effect of partial decay of cellulose on the isotopic signature of tree rings and its implications for paleoclimate reconstructions is insufficiently investigated, although results from naturally degraded subfossil wood show no evidence for a change in the isotopic composition of cellulose due to degradation (Loader et al., 2003).

While studies on CC (\%) and its implication for dendroclimatological studies are scarce, even less is known about the influence of environmental conditions on the annual variability of the CC (\%) (Genet et al., 2011). For instance, Gindl et al. (2000) discussed lignin content as a temperature proxy for the late growing season (September-October). As lignin and cellulose are among the major components of a tree ring, and changes in one component affect the cellulose/lignin ratio, a link between $\mathrm{CC}(\%)$ and temperature can be expected as well. However, the study of Gindl et al. (2000) covers only a short time period of 10 years and the method used is rather time consuming, whereas the production of $\mathrm{CC}(\%)$ is often a by-product during the extraction of $\alpha$-cellulose for stableisotope analysis in tree rings. A study on $\mathrm{CC}(\%)$ in roots revealed influences of topography and soil moisture status on root CC (\%) (Hales et al., 2009). However, variations in $\mathrm{CC}(\%)$ over time may also be related to tree metabolism and the availability in non-structural carbon (NSC), which occurs in the form of starch and sugars. The sugars provide the nutrients for cell wall components such as cellulose (Haigler et al., 2001; Hoch et al., 2002). Studies on NSC concentrations at the Alpine treeline provide evidence that trees growing in the treeline ecotone are not depleted in carbon; on the contrary, NSC concentrations are found to increase with elevation, implying that the limitation of tree growth at the upper treeline does not result from insufficient nutrition but rather thermal conditions, i.e. temperature, which limits the sink activity and thereby growth (Hoch et al., 2002; Hoch and Körner, 2003, 2009, 2012; Körner, 2003). Applied to the $\mathrm{CC}(\%)$ of a tree ring, it can be hypothesised that temperature acts as the main control, as it steers the sink activity, i.e. tissue formation.

This paper presents the results of a pilot study in which time series of modern and subfossil tree-ring cellulose are established, allowing a novel insight into a tree-ring component which is commonly used in dendroclimatology but hardly examined itself in its variability over time and in the factors driving its variability.

The current study is embedded in the project Alpine Holocene Tree Ring Isotope Records (AHTRIR), which aims to reconstruct Holocene climate variability using a multiproxy approach for the past 9000 years. Therefore, tree-ring 
material consists only partly of living wood material; by far the largest part is based on findings of Holocene wood remains from glacier forefields, peat bogs and small lakes in the central European Alps. Initially, the determination of $\mathrm{CC}(\%)$ was used to determine the quality of the cellulose extraction before performing an analysis of triple isotopes $\left(\delta^{2} \mathrm{H}, \delta^{18} \mathrm{O}, \delta^{13} \mathrm{C}\right)$ on the tree-ring cellulose. However, it offers a unique opportunity to investigate the $\mathrm{CC}(\%)$ and its variations in long-living trees from two high-Alpine coniferous tree species (Larix decidua Mill. and Pinus cembra L.) in Holocene wood remains found in glacier forefields and peat bogs in the European Alps as well as in modern trees sampled at the current Alpine tree line. The case study aims to (i) identify common trends in time series of $\mathrm{CC}(\%)$ in tree rings from Early and mid-Holocene subfossil and modern wood material; (ii) investigate dependencies of $\mathrm{CC}(\%)$ in relation to their sampling site (latitude, longitude, elevation), their age and the species; (iii) analyse climate-CC (\%) relationships and finally (iv) determine the ability to utilise $\mathrm{CC}(\%)$ as a supplementary proxy in dendroclimatological reconstructions.

\section{Material and methods}

\subsection{Samples and sampling sites}

Holocene wood remains and modern tree-ring material are sampled with the intent to reconstruct Holocene climate variability in a multi-proxy approach. Thereby, samples from two Alpine treeline species, namely the Swiss stone pine ( $P i$ nus cembra L., PICE) and the European larch (Larix decidua Mill., LADE) are collected as they represent the typical treeline species present at modern sampling sites in the form of living trees, and in glacier forefields and peat bogs as subfossil wood remains (Joerin et al., 2008; Nicolussi, et al., 2009; Nicolussi and Patzelt, 2000a). The sampling sites are located along a SW-NE transect in the central European Alps $\left(46^{\circ} 02-47^{\circ} 03^{\prime} \mathrm{N}, 7-12^{\circ} 15^{\prime} \mathrm{E}\right.$; Fig. 1, Tables 1 and 2). The modern tree-ring material was cored at three upper treeline sites close to the glacier forefield sites during fieldwork in 2015 (Fig. 2, Table 1). At each site, four trees per species were cored; however, at the sites UAZR and FPCR, only one of the two species is present. Cores are taken at breast height from three radial sections, two in parallel to the slope and one up-slope, thereby avoiding any kind of compression wood on the down-slope side of the tree.

The Holocene wood remains stem from glacier forefields, peat bogs and small lakes and have been continuously collected over the last two decades (Joerin et al., 2006, 2008; Nicolussi, et al., 2009; Nicolussi et al., 2005; Nicolussi and Patzelt, 2000b). Wood material from the EACC (Eastern Alpine Conifer Chronology) has been merged and updated with subfossil samples of the same species and altitude collected by continued sampling of wood remains and stem

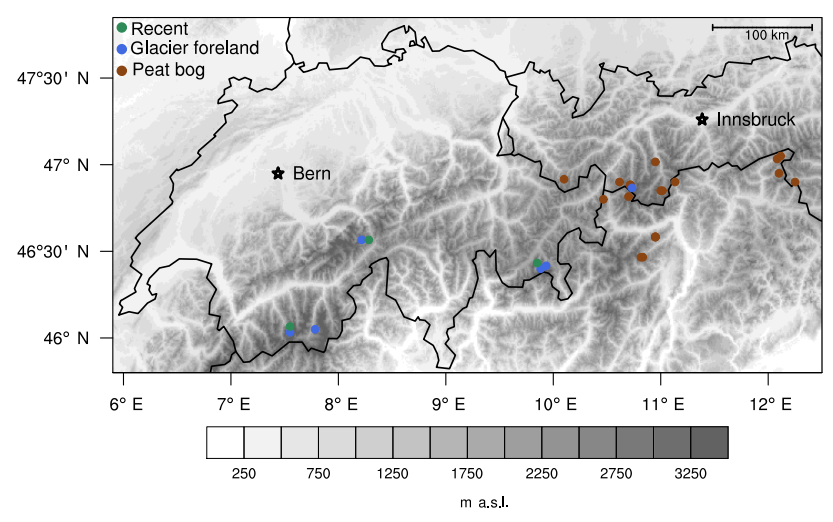

Figure 1. Sampling sites of Holocene wood remains and living tree individuals. The sites are located along a SW-NE transect along the central European Alps and contain glacier forefields (blue), peat bogs and small lakes (maroon), where Holocene wood remains are collected, and modern sites, where living trees were cored (green). The modern sites are situated in the proximity of glacier forefield sites, thereby resembling similar growth conditions and serving as a connection between Holocene and present-day tree growth and environmental conditions (source: M. Messmer).

discs in glacier forefields (Nicolussi and Schlüchter, 2012). Similarly to modern wood samples, the use of compression wood in these Holocene samples was avoided during further analysis.

\subsection{Tree ring width and dating}

Total tree-ring width (TRW) is measured for all samples. At least two radii are measured per tree with a precision of $0.001 \mathrm{~mm}$ by using a LINTAB device in connection to TSAPWin software (Rinn, 1996). For each sample, a mean TRW series is established by cross-dating and averaging the radii per tree. If the inner part of the stem is missing in a tree-ring series, the tree-ring number between the pith and the first tree ring measured is estimated (pith-offset, PO; Table 3). For the modern series, dating is simple as the exact sampling date is known. For the Holocene wood remains, the mean series are compared to local tree-ring series and reference chronologies (Nicolussi et al., 2009; Nicolussi and Schlüchter, 2012). Cross-dating is achieved by calculating statistical parameters and applying visual controls.

\subsection{Sample preparation}

Samples for CC (\%) analysis are prepared as 5-year tree-ring blocks per tree, thus no pooling between trees is applied. For the Holocene samples, radial wedges are cut out of stem disks by using a bandsaw. Subsequently, blocks are prepared from the wedges and the cores under the microscope by using a commercial scalpel. The dry weight of each block is scaled and is defined to be between 20 and $50 \mathrm{mg}$, as a $60 \%$ weight loss is expected during $\alpha$-cellulose extraction. Further, the 
Table 1. Site characteristics of modern sites. Coordinates, aspect and elevation describe their geographical distribution from west to east. Four trees are sampled per site and species, resulting in eight trees cored at VRR, where both species are present at the treeline. Site characteristics are complemented by the maximum growth period and the period covered by a sample replication of four trees in years AD as well as the mean segment length (MSL) in years.

\begin{tabular}{|c|c|c|c|c|}
\hline Site code & & FPCR & UAZR & VRR \\
\hline Sampling site & & $\begin{array}{l}\text { Val d'Hérens, Mont Miné } \\
\text { glacier }\end{array}$ & $\begin{array}{l}\text { Haslital, Unteraar } \\
\text { glacier, north shore Grimsel } \\
\text { reservoir }\end{array}$ & Val Roseg \\
\hline \multirow[t]{9}{*}{ Site character } & Site type & near timberline & near timberline & near timberline \\
\hline & Latitude $^{\circ} \mathrm{N}$ & $46^{\circ} 04^{\prime} \mathrm{N}$ & $46^{\circ} 34^{\prime} \mathrm{N}$ & $46^{\circ} 26^{\prime} \mathrm{N}$ \\
\hline & Longitude ${ }^{\circ} \mathrm{E}$ & $7^{\circ} 33^{\prime} \mathrm{E}$ & $8^{\circ} 17^{\prime} \mathrm{E}$ & $9^{\circ} 51^{\prime} \mathrm{E}$ \\
\hline & Aspect & WSW & SSO & $\mathrm{E}$ \\
\hline & $\begin{array}{l}\text { Elevation } \\
\text { (m a.s.1.) }\end{array}$ & 1930-2000 & 1968-1986 & $2127-2190$ \\
\hline & $\begin{array}{l}\text { Number of } \\
\text { trees }\end{array}$ & 4 & 4 & 8 \\
\hline & Period AD & $1680-2015$ & $1810-2015$ & $1630-2015$ \\
\hline & $\begin{array}{l}\text { Period AD with } \\
\text { replication } \geq 4\end{array}$ & 1860-2015 & $1865-2015$ & $\begin{array}{l}1845-2015 \\
(\mathrm{PICE}) / 1865- \\
2015(\mathrm{LADE})\end{array}$ \\
\hline & $\begin{array}{l}\text { Mean segment } \\
\text { length (years) }\end{array}$ & 208 & 173 & $\begin{array}{l}209 \text { (PICE)/219 } \\
(\mathrm{LADE})\end{array}$ \\
\hline
\end{tabular}
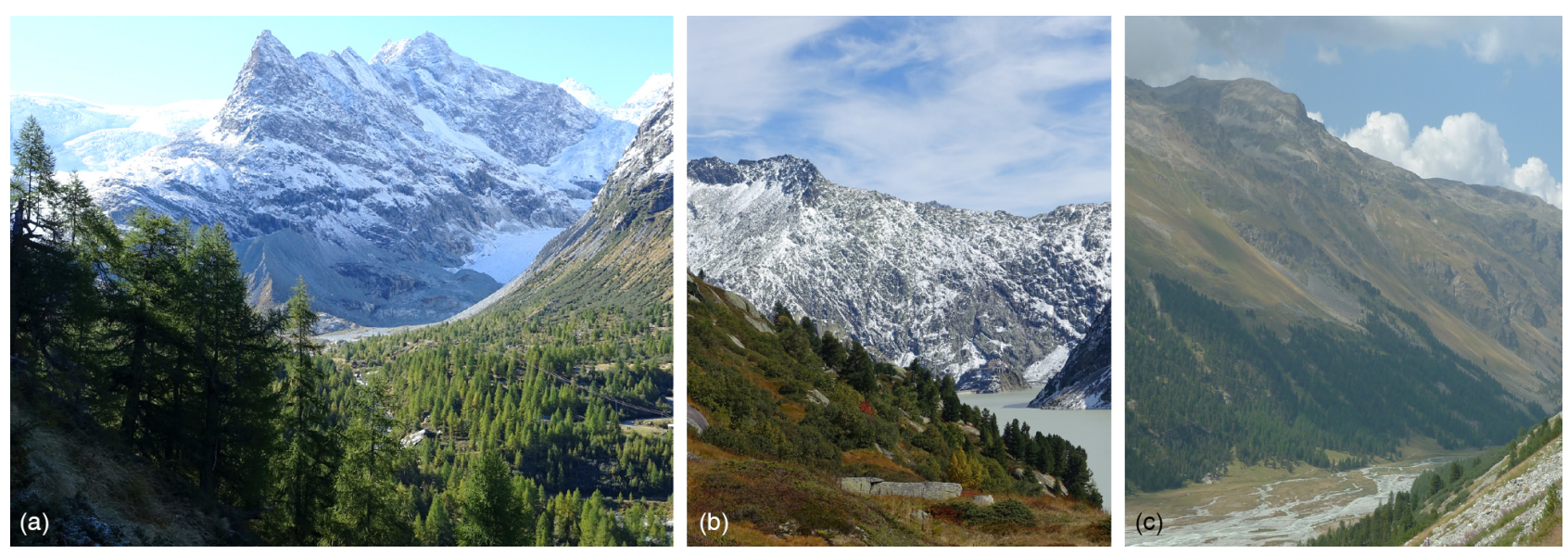

Figure 2. Location of modern sampling sites at the Alpine treeline at Mont Miné glacier (FPCR, a), in front of Unteraar glacier (UAZR, b) and in the Val Roseg close to the Tschierva glacier (VRR, c) (source: K. Nicolussi).

incipient degradation in the samples might have additionally reduced the $\mathrm{CC}(\%)$. The blocks are further cut into small slices of wood material by first being sliced in parallel to the fibre direction and subsequently against the fibre direction. The resulting size of the cut sample is $<1 \mathrm{~mm}$. Again, the dry weight of the cut sample is scaled to estimate the loss during the cutting procedure. For the following chemical treatment, the samples are packed into ANKOM filter bags (type F57), heat-sealed and labelled individually.

\subsection{Cellulose extraction}

The cellulose extraction is based on a modified Jayme-Wise procedure (Boettger et al., 2007; Borella et al., 1999; Leuenberger, 1998). The bleaching (delignification) of samples in a $1 \% \mathrm{NaClO}_{2}+\mathrm{CH}_{3} \mathrm{COOH}$ solution with a $\mathrm{pH}$ value of 4 is conducted at $70{ }^{\circ} \mathrm{C}$ for at least $30 \mathrm{~h}$ to remove lignin. In a second step, samples are treated in a $17 \% \mathrm{NaOH}$ solution at $25^{\circ} \mathrm{C}$ for $45 \mathrm{~min}$ to extract the pure $\alpha$-cellulose (Burton and Rasch, 1931; Cross and Bevan, 1912). Subsequently, samples are neutralised in a $1 \% \mathrm{HCl}$ solution using $25 \% \mathrm{HCl}$ and washed intensely with heated and cold distilled water 
Table 2. Site characteristics of Holocene sites. Given are the site codes as well as the geographic location expressed by latitude, longitude and aspect. Elevation of sampling sites is comparable with modern sampling sites, occasionally exceeding the current treeline.

\begin{tabular}{|c|c|c|c|c|c|c|}
\hline \multirow[t]{2}{*}{ Site code } & \multirow[t]{2}{*}{ Sampling site } & \multicolumn{5}{|c|}{ Site character } \\
\hline & & Site type & Latitude $^{\circ} \mathrm{N}$ & Longitude ${ }^{\circ} \mathrm{E}$ & Aspect & Elevation (m a.s.1.) \\
\hline ahmo & Ahrntal, Moaralm & peat bog & $47^{\circ} 02^{\prime} \mathrm{N}$ & $12^{\circ} 05^{\prime} \mathrm{E}$ & SE & 1995 \\
\hline ahst & Ahrntal, Starklalm & peat bog & $47^{\circ} 03^{\prime} \mathrm{N}$ & $12^{\circ} 07^{\prime} \mathrm{E}$ & $\mathrm{S}$ & 2080 \\
\hline bih & Paznaun, Bielerhöhe & peat bog & $46^{\circ} 55^{\prime} \mathrm{N}$ & $10^{\circ} 06^{\prime} \mathrm{E}$ & $\mathrm{N}$ & 1930-2020 \\
\hline eba & Ötztal, Ebenalm & lake/peat bog & $47^{\circ} 01^{\prime} \mathrm{N}$ & $10^{\circ} 57^{\prime} \mathrm{E}$ & NO & $2060-2170$ \\
\hline $\mathrm{g}$ & Ötztal, Gurgler Zirbenwald & peat bog & $46^{\circ} 51^{\prime} \mathrm{N}$ & $11^{\circ} 01^{\prime} \mathrm{E}$ & NW & 2060 \\
\hline $\mathrm{gdm}$ & Kaunertal, Daunmoränensee & lake/peat bog & $46^{\circ} 53^{\prime} \mathrm{N}$ & $10^{\circ} 43^{\prime} \mathrm{E}$ & $\mathrm{O}$ & 2295 \\
\hline ggua & Ötztal, Gurgler Alm & peat bog & $46^{\circ} 51^{\prime} \mathrm{N}$ & $11^{\circ} 00^{\prime} \mathrm{E}$ & $\mathrm{W}$ & $2150-2200$ \\
\hline gli & Kaunertal, Ombrometer & peat bog & $46^{\circ} 53^{\prime} \mathrm{N}$ & $10^{\circ} 43^{\prime} \mathrm{E}$ & NO & $2135-2160$ \\
\hline gp & Kaunertal, Gepatschferner & glacier foreland & $46^{\circ} 52^{\prime} \mathrm{N}$ & $10^{\circ} 44^{\prime} \mathrm{E}$ & $\mathrm{W}$ & $2060-2275$ \\
\hline hib & Defereggental, Hirschbichl & lake/peat bog & $46^{\circ} 54^{\prime} \mathrm{N}$ & $12^{\circ} 15^{\prime} \mathrm{E}$ & $\mathrm{E}$ & 2140 \\
\hline kofl & Ahrntal, Kofler Alm & peat bog & $46^{\circ} 57^{\prime} \mathrm{N}$ & $12^{\circ} 06^{\prime} \mathrm{E}$ & $\mathrm{S}$ & $2165-2190$ \\
\hline mazb & Vinschgau, Marzoneralm/B & peat bog & $46^{\circ} 35^{\prime} \mathrm{N}$ & $10^{\circ} 57^{\prime} \mathrm{E}$ & $\mathrm{N}$ & 2125 \\
\hline mazc & Vinschgau, Marzoneralm/C & peat bog & $46^{\circ} 35^{\prime} \mathrm{N}$ & $10^{\circ} 57^{\prime} \mathrm{E}$ & $\mathrm{N}$ & 2120 \\
\hline maze & Vinschgau, Marzoneralm/E & peat bog & $46^{\circ} 35^{\prime} \mathrm{N}$ & $10^{\circ} 57^{\prime} \mathrm{E}$ & $\mathrm{N}$ & 2125 \\
\hline $\mathrm{mm}$ & Val d'Hérens, Mont Miné glacier & glacier foreland & $46^{\circ} 02^{\prime} \mathrm{N}$ & $7^{\circ} 55^{\prime} \mathrm{E}$ & $\mathrm{NNE}$ & 1980-2010 \\
\hline mort & Morteratsch glacier & glacier foreland & $46^{\circ} 25^{\prime} \mathrm{N}$ & $9^{\circ} 56^{\prime} \mathrm{E}$ & $\mathrm{W}$ & 2040-2050 \\
\hline $\mathrm{rt}$ & Rojental & lake/peat bog & $46^{\circ} 48^{\prime} \mathrm{N}$ & $10^{\circ} 28^{\prime} \mathrm{E}$ & SO & 2400 \\
\hline $\operatorname{tah}$ & Passeier, Timmeltal & peat bog & $46^{\circ} 54^{\prime} \mathrm{N}$ & $11^{\circ} 08^{\prime} \mathrm{E}$ & $\mathrm{S}$ & $1975-2260$ \\
\hline tsc & Val Roseg, Tschierva glacier & glacier foreland & $46^{\circ} 24^{\prime} \mathrm{N}$ & $9^{\circ} 53^{\prime} \mathrm{E}$ & NW & $2115-2210$ \\
\hline ua & Haslital, Unteraar glacier & glacier foreland & $46^{\circ} 34^{\prime} \mathrm{N}$ & $8^{\circ} 13^{\prime} \mathrm{E}$ & $\mathrm{E}$ & 1950 \\
\hline ulfi & Ultental, Fiechtsee & lake/peat bog & $46^{\circ} 28^{\prime} \mathrm{N}$ & $10^{\circ} 50^{\prime} \mathrm{E}$ & $\mathrm{N}$ & 2110 \\
\hline uwba & Ultental, Weißbrunnalm & peat bog & $46^{\circ} 28^{\prime} \mathrm{N}$ & $10^{\circ} 49^{\prime} \mathrm{E}$ & $\mathrm{NE}$ & 2330 \\
\hline zer & Mattertal, Zermatt, Findel glacier & glacier foreland & $46^{\circ} 03^{\prime} \mathrm{N}$ & $7^{\circ} 47^{\prime} \mathrm{E}$ & $\mathrm{N}$ & $2300-2330$ \\
\hline
\end{tabular}

until the $\mathrm{pH}$ of the washing water is $\sim 7$. Samples are dried in an oven at $50^{\circ} \mathrm{C}$; the duration of the drying is thereby dependent on the sample size in the individual filter bags.

\subsection{Calculation of $\mathrm{CC}(\%)$}

The CC $(\%)$ is calculated from the dry weight of wood and the $\alpha$-cellulose weight of a sample:

$\mathrm{CC}(\%)=\left(\frac{\alpha \text {-cellulose weight }}{\text { wood dry weight }}\right) \times 100 \%$.

The wood dry weight is thereby defined as the sample weight of the individual wood sample after cutting, and the cellulose weight refers to the weight of the extracted $\alpha$-cellulose after being removed from the ANKOM filter bag.

A remaining source of error is the collection of dry $\alpha$ cellulose from the ANKOM filter bags. The described slicing of wood samples facilitates the removal of $\alpha$-cellulose from filter bags compared to ground wood samples and thereby reduces the loss of $\alpha$-cellulose material when it is collected from the filter bags. In this study, the resulting loss is examined for 42 samples, for which the filter bag including the $\alpha$-cellulose and the emptied filter bag are scaled in addition to the $\alpha$-cellulose weight to give an accurate estimate of the observed loss.

\subsection{Outlier detection and correction}

Outliers in CC (\%) are observed for Holocene wood remains, for which the outermost rings have experienced a higher degree of degradation, e.g. due to abrasion at the glacier sites or the exposition of wood to environmental influences and associated weathering of the sample. The differential grades of degradation lead to pronounced decreases in $\mathrm{CC}(\%)$ appearing within the outermost rings but also along cracks between individual rings and occasionally on the innermost parts of trees, which complicates the comparison of individual time series. Therefore, detection and elimination of outliers are performed by visual and statistical application of box plots (Tukey, 1977). Tukey (1977) defines outliers as samples, which lie outside the whiskers, whereby the extension of the whisker is limited by the 1.5 interquartile range (IQR). In addition to the box plots, visual comparisons of suspicious samples with other cellulose series are applied; thereby outliers close to the whiskers were revealed to be true values and the loss of samples by outlier detection and elimination could be minimised to the most extreme values.

\subsection{Meteorological data}

$\mathrm{CC}(\%)$ series of modern sampling sites are correlated with meteorological data from the HISTALP database to investi- 
Table 3. Individual tree characteristics per modern sampling site. Given are the tree species, start and end date of the $\alpha$-cellulose content series in years b2k and years AD in brackets, respectively. The length of the individual series is enlisted in years and the estimation of the pith offset (PO) in annual resolution and calculated as the number of 5-year blocks. The number of 5-year cellulose blocks covering the length of the cellulose series is shown.

\begin{tabular}{|c|c|c|c|c|c|c|c|}
\hline Sample & Species & Start - years b2k (AD) & End - years b2k (AD) & years & $\mathrm{PO}$ & $\begin{array}{r}\mathrm{PO} \\
(5 \text {-year blocks })\end{array}$ & $\begin{array}{r}\text { Number of } \\
\text { samples (5-year blocks) }\end{array}$ \\
\hline UAZR-1 & PICE & 135 (1865 AD) & $-14(2014 \mathrm{AD})$ & 150 & 50 & 10 & 30 \\
\hline UAZR-2 & PICE & 140 (1860 AD) & $-14(2014 \mathrm{AD})$ & 155 & 82 & 17 & 31 \\
\hline UAZR-3 & PICE & 165 (1835 AD) & $-14(2014 \mathrm{AD})$ & 180 & 61 & 13 & 36 \\
\hline UAZR-4 & PICE & 190 (1810 AD) & $-14(2014 \mathrm{AD})$ & 205 & 32 & 7 & 41 \\
\hline FPCR-1 & LADE & 320 (1680 AD) & $-14(2014 \mathrm{AD})$ & 335 & 150 & 30 & 67 \\
\hline FPCR-3 & LADE & 155 (1845 AD) & $-14(2014 \mathrm{AD})$ & 170 & 30 & 6 & 34 \\
\hline FPCR-5 & LADE & 155 (1845 AD) & $-14(2014 \mathrm{AD})$ & 170 & 45 & 9 & 34 \\
\hline FPCR-6 & LADE & 140 (1860 AD) & $-14(2014$ AD) & 155 & 55 & 11 & 31 \\
\hline VRR-1 & PICE & 205 (1795 AD) & $-14(2014 \mathrm{AD})$ & 220 & 62 & 13 & 44 \\
\hline VRR-1-2 & PICE & 195 (1805 AD) & $-14(2014 \mathrm{AD})$ & 205 & 77 & 15 & 41 \\
\hline VRR-3 & PICE & 175 (1825 AD) & $-14(2014 \mathrm{AD})$ & 190 & 12 & 3 & 38 \\
\hline VRR-4 & PICE & 155 (1845 AD) & $-14(2014$ AD) & 170 & 49 & 10 & 34 \\
\hline VRR-5 & PICE & 240 (1760 AD) & $-14(2014 \mathrm{AD})$ & 255 & 13 & 3 & 51 \\
\hline VRR-6 & LADE & 135 (1865 AD) & $-14(2014 \mathrm{AD})$ & 150 & 6 & 2 & 30 \\
\hline VRR-7 & LADE & 135 (1865 AD) & $-14(2014 \mathrm{AD})$ & 150 & 13 & 3 & 30 \\
\hline VRR-8 & LADE & $370(1630 \mathrm{AD})$ & $-14(2014 \mathrm{AD})$ & 385 & 27 & 6 & 77 \\
\hline VRR-9 & LADE & 175 (1825 AD) & $-14(2014 \mathrm{AD})$ & 190 & 25 & 5 & 38 \\
\hline
\end{tabular}

gate the relationship between climate and CC (\%) (Auer et al., 2007). Data are obtained in the form of coarse-resolution subregional means (CRSM), calculated as arithmetic means from homogenised individual station series for five defined subregions within the Greater Alpine Region (GAR), which have been identified by EOF-based regionalisation. Auer et al. (2007) especially recommend CRSM series for lowerfrequency analysis for all climate parameters. Series from the sampling sites FPCR and UAZR are correlated to meteorological data from the NW subregion, and from VRR to data from the SW region, respectively, due to their geographical location.

For these subregions, monthly anomalies (calculated for the reference period 1961-1990) of temperature $\left(T\left({ }^{\circ} \mathrm{C}\right)\right.$, 1760-2008), precipitation (PREC (mm), 1800-2008), cloud cover (CLOUD (\%), 1840-2008) and sunshine (SUN (h), 1880-2008), including the arithmetic seasonal (MAM, JJA, SON, DJF), semi-annual (AMJJAS, ONDJFM) and annual means are extracted. For further analysis, 5-year mean values are calculated for the annually resolved climate data as $\mathrm{CC}(\%)$ series were established in 5-year resolution and thereby integrate the mean climatic signal over five consecutive years.

Pearson's correlation coefficient is calculated between the mean CC (\%) series per site and species, and the monthly, seasonal and annual values for the four climate variables for the time period 1865-2008 (1880-2008 in case of sunshine). We assume here that each data point (5-year blocked data) in the climate variable data sets and the $\mathrm{CC}(\%)$ series is independent, since there is no data point overlap.

\section{Results}

As the precise calculation of the $\mathrm{CC}(\%)$ depends on error estimates for the dry weight of samples and the cellulose weight, two steps in the calculation of CC $(\%)$ are improved here: the precision of dry weight and the loss estimation in cellulose weight.

The mean sample loss during the cutting process amounts to $2.6 \pm 1.7 \%$ of the dry weight of an individual sample, for which mean loss values range from 0.3 up to $11.1 \%$ per tree (data not shown here). Besides, very few individual samples experienced losses between 10 and $30 \%$ caused by wood pieces bouncing off during cutting or loss of material due to powdery wood substance as a result of degradation. Hence, for the precise calculation of $\mathrm{CC}(\%)$, a determination of the sample weight after cutting or milling is essential.

Secondly, when unpacking the cellulose material from the filter bags, there is always a risk that smallest fibres remain in the filter bag or fly away during the removal; therefore, we assume this error to be systematic. In this study, we estimated this error by analysing 42 filter bags, which revealed a mean loss of $\alpha$-cellulose of $0.378 \pm 0.163 \mathrm{mg}(3.2 \pm 1.4 \%)$ (Table 4). Therefore, the calculation of the CC (\%) results in the minimum CC $(\%)$ of the sample, as losses of cellulose of the order of $3.2 \pm 1.4 \%$ of the cellulose weight are to be ex- 
Table 4. Calculated sample loss during unpacking of extracted $\alpha$-cellulose from ANKOM filter bags (type F57) for 42 samples (sample tree MM-602, PICE). The expected sample weight is calculated by subtracting the scaled weight of the emptied filter bag from the weight of the filled bag. The difference between the expected weight of $\alpha$-cellulose and the scaled weight of unpacked cellulose defines the loss, which is given here in $(\mathrm{mg})$ and $(\%)$.

\begin{tabular}{|c|c|c|c|c|c|c|}
\hline Sample & $\begin{array}{r}\text { Bag including } \\
\text { sample (mg) }\end{array}$ & $\begin{array}{r}\text { Emptied } \\
\text { bag }(\mathrm{mg})\end{array}$ & $\begin{array}{r}\text { Expected sample } \\
\text { weight }(\mathrm{mg})\end{array}$ & $\begin{array}{r}\text { Sample } \\
\text { weight }(\mathrm{mg})\end{array}$ & $\begin{array}{l}\text { Loss } \\
(\mathrm{mg})\end{array}$ & $\begin{array}{r}\text { Loss } \\
(\%)\end{array}$ \\
\hline 1 & 138.250 & 126.552 & 11.698 & 11.473 & 0.225 & 1.9 \\
\hline 2 & 138.112 & 128.480 & 9.632 & 9.307 & 0.325 & 3.4 \\
\hline 3 & 129.500 & 116.654 & 12.846 & 12.293 & 0.553 & 4.3 \\
\hline 4 & 147.350 & 134.918 & 12.432 & 11.980 & 0.452 & 3.6 \\
\hline 5 & 129.060 & 118.279 & 10.781 & 10.405 & 0.376 & 3.5 \\
\hline 6 & 133.301 & 123.375 & 9.926 & 9.731 & 0.195 & 2.0 \\
\hline 7 & 147.471 & 132.364 & 15.107 & 14.758 & 0.349 & 2.3 \\
\hline 8 & 136.276 & 123.247 & 13.029 & 12.486 & 0.543 & 4.2 \\
\hline 9 & 147.790 & 134.199 & 13.591 & 13.011 & 0.580 & 4.3 \\
\hline 10 & 136.433 & 125.743 & 10.690 & 10.341 & 0.349 & 3.3 \\
\hline 11 & 132.212 & 121.153 & 11.059 & 10.708 & 0.351 & 3.2 \\
\hline 12 & 133.778 & 119.853 & 13.925 & 13.553 & 0.372 & 2.7 \\
\hline 13 & 145.170 & 133.002 & 12.168 & 11.667 & 0.501 & 4.1 \\
\hline 14 & 140.314 & 128.114 & 12.200 & 11.804 & 0.396 & 3.2 \\
\hline 15 & 118.253 & 108.009 & 10.244 & 10.211 & 0.033 & 0.3 \\
\hline 16 & 127.516 & 115.089 & 12.427 & 12.004 & 0.423 & 3.4 \\
\hline 17 & 124.031 & 111.314 & 12.717 & 11.733 & 0.984 & 7.7 \\
\hline 18 & 123.409 & 113.444 & 9.965 & 9.704 & 0.261 & 2.6 \\
\hline 19 & 127.960 & 119.475 & 8.485 & 8.228 & 0.257 & 3.0 \\
\hline 20 & 154.157 & 136.382 & 17.775 & 17.348 & 0.427 & 2.4 \\
\hline 21 & 138.214 & 126.419 & 11.795 & 11.321 & 0.474 & 4.0 \\
\hline 22 & 114.291 & 101.147 & 13.144 & 12.823 & 0.321 & 2.4 \\
\hline 23 & 136.587 & 125.258 & 11.329 & 11.305 & 0.024 & 0.2 \\
\hline 24 & 121.803 & 107.166 & 14.637 & 14.383 & 0.254 & 1.7 \\
\hline 25 & 130.931 & 116.707 & 14.224 & 13.969 & 0.255 & 1.8 \\
\hline 26 & 138.189 & 126.357 & 11.832 & 11.503 & 0.329 & 2.8 \\
\hline 27 & 128.379 & 114.667 & 13.712 & 13.430 & 0.282 & 2.1 \\
\hline 28 & 132.578 & 120.533 & 12.045 & 11.402 & 0.643 & 5.3 \\
\hline 29 & 131.704 & 119.411 & 12.293 & 11.726 & 0.567 & 4.6 \\
\hline 30 & 113.811 & 102.525 & 11.286 & 10.972 & 0.314 & 2.8 \\
\hline 31 & 120.800 & 109.288 & 11.512 & 11.310 & 0.202 & 1.8 \\
\hline 32 & 116.480 & 102.682 & 13.798 & 13.321 & 0.477 & 3.5 \\
\hline 33 & 125.114 & 112.714 & 12.400 & 12.036 & 0.364 & 2.9 \\
\hline 34 & 119.056 & 107.090 & 11.966 & 11.530 & 0.436 & 3.6 \\
\hline 35 & 121.489 & 109.201 & 12.288 & 11.951 & 0.337 & 2.7 \\
\hline 36 & 106.796 & 92.591 & 14.205 & 13.770 & 0.435 & 3.1 \\
\hline 37 & 126.301 & 111.446 & 14.855 & 14.389 & 0.466 & 3.1 \\
\hline 38 & 127.248 & 113.117 & 14.131 & 13.642 & 0.489 & 3.5 \\
\hline 39 & 156.524 & 143.516 & 13.008 & 12.529 & 0.479 & 3.7 \\
\hline 40 & 130.215 & 121.632 & 8.583 & 8.347 & 0.236 & 2.7 \\
\hline 41 & 144.788 & 140.079 & 4.709 & 4.362 & 0.347 & 7.4 \\
\hline 42 & 123.144 & 109.257 & 13.887 & 13.681 & 0.206 & 1.5 \\
\hline
\end{tabular}

pected, which would result in slightly increased CC (\%) values. However, as the unpacking is accomplished equally for all samples, a systematic error is assumed which affects the $\mathrm{CC}(\%)$ calculation in the same manner. It can be assumed that the systematic error does not influence the variability of the individual $\mathrm{CC}(\%)$ series.
Further, the relative uncertainty in cellulose weight transfers directly to the relative uncertainty in $\mathrm{CC}(\%)$ determination as relative uncertainties are additive, with the uncertainty of the dry weight after cutting being negligible. Relevant for the $\mathrm{CC}(\%)$ variation is the variation of the relative uncertainty $( \pm 1.4 \%)$ and not the relative uncertainty itself $(3.2 \%)$, which only yields a mean offset of the whole 

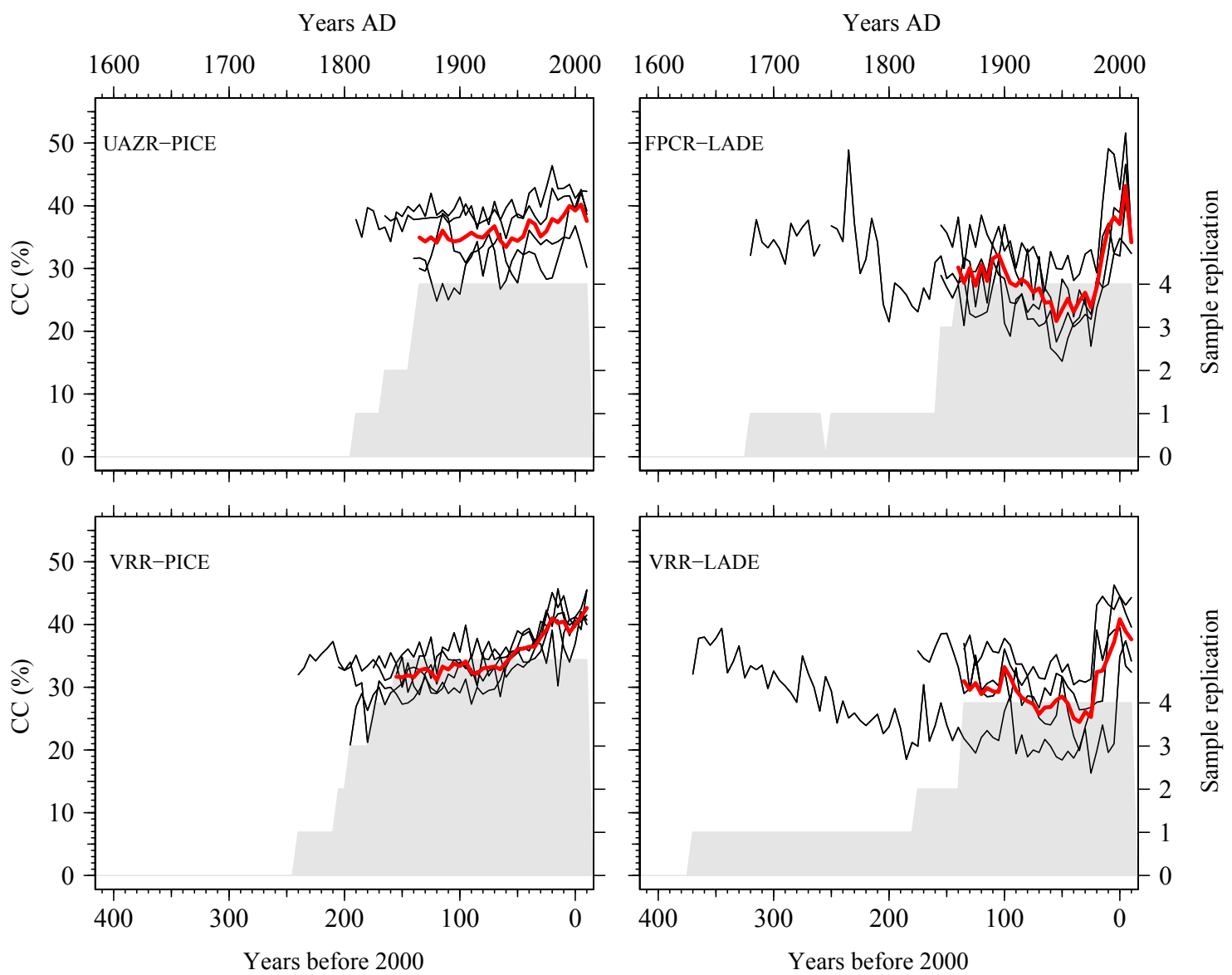

Figure 3. Individual cellulose content series for two coniferous species (LADE, PICE) at the modern sites. The individual cellulose content time series (black lines) are supplemented by the mean cellulose content per species and site (red line), calculated as the arithmetic mean of the individual trees for the common growth period (sample replication $\geq 4$ ). The sample replication (grey area) displays the temporal coverage per site.

curve. Although the relative uncertainty slightly limits the interpretation of minor differences between the individual 5year CC (\%) samples, it does not limit the investigation of trends in $\mathrm{CC}(\%)$ series.

The improvement in the $\mathrm{CC}(\%)$ calculation and the estimation of the relative error justify the use of the term "CC (\%)" rather than "cellulose yield", as sources of error are reduced and well estimated, and resulting calculations are close to the true values.

\subsection{Modern CC (\%) series}

For a better understanding of $\mathrm{CC}(\%)$ variations, modern $\mathrm{CC}(\%)$ series are analysed for their temporal variability per species and site, for which the absolute values and variations in $\mathrm{CC}(\%)$ are given in the unit $\mathrm{CC} \%$. Trees sampled at UAZR consist solely of PICE samples, as the treeline at that site is only composed of one tree species. Measured tree-ring width series vary in length between 150 and 205 years; the pith offset estimation varies between 32 and 82 for the individual trees (Table 3). The mean segment length (MSL) amounts to 173 years and the period covered by all four samples spans from 1860 to 2014 AD (Table 1). The mean cellulose content per tree varies between 31.6 and $39.7 \mathrm{CC} \%$, where UAZR-1 $(33.2 \mathrm{CC} \%)$ and UAZR-2 $(33.2 \mathrm{CC} \%)$ show distinctly lower mean $\mathrm{CC}(\%)$ values as UAZR-3 (38.6 CC \%) and UAZR-4 (39.7 CC \%). These differences are a result of low minimum values for UAZR-1 and UAZR-2, which are up to $10 \mathrm{CC} \%$ lower than for the other two trees (Table 5). Further, the time series of CC (\%) for UAZR-1 and -2 show more variability in their series compared to UAZR-3 and -4, which show high common variability and very small fluctuations in their $\mathrm{CC}(\%)$. This is further confirmed by the calculated Pearson's correlation coefficient $(\mathrm{r})$, with the highest values for UAZR-3 and $-4(r=0.64)$ (Table 6). A significant correlation is also found between UAZR-2 and $-3(r=0.36)$, whereas the remaining correlation coefficients are non-significant $(p>0.05)$. The arithmetic mean calculated from four samples in their common 
period (1860-2015 AD) indicates an increase in CC (\%) over time by $\sim 5 \mathrm{CC} \%$ (red line, Fig. 3, top left).

In contrast to UAZR, the sampling site FPCR consists solely of LADE trees, while tree-ring series contain between 155 and 335 years. The MSL amounts to 208 years, raised by the sample FPCR-1 (335 years), whereas the residual tree-ring series consist of 155 and 170 years (Table 1, Table 3). The four tree samples cover a common period from 1860 to $2015 \mathrm{AD}$ (Table 1). The mean CC (\%) per tree varies between 28.3 and $32.9 \mathrm{CC} \%$, showing overall lower mean $\mathrm{CC}(\%)$ values than observed for the PICE trees at UAZR (Table 5). Further, the range of $\mathrm{CC}(\%)$ per individual tree is large, as LADE trees show low minimum $\mathrm{CC}(\%)$ values between 15.2 and $21.8 \mathrm{CC} \%$ as well as high maximum values of up to $51.6 \mathrm{CC} \%$ (Table 5). In their common period, trees at FPCR show a decrease in CC (\%) from 1860 to $1945 \mathrm{AD}$ and a strong increase of nearly $20 \mathrm{CC} \%$ from 1980 to $2014 \mathrm{AD}$, which is common among the individual trees (Fig. 3, top right). Pearson's correlation coefficient illustrates the common variability among the samples FPCR$1,-5$ and -6 , showing high correlation coefficient between 0.67 and 0.79 , whereas non-significant and lower correlation coefficients are found for FPCR-3 (Table 6).

The sampling site VRR located in the Val Roseg in eastern Switzerland, and in the proximity of the Tschierva glacier, is the only sampling site where both tree species, LADE and PICE are found, thereby allowing a direct comparison of species under the same climatic growing conditions.

PICE trees at VRR exhibit tree-ring series of 170 to 255 years, with a common period between 1845 and 2015 $\mathrm{AD}$ and a MSL of 209 years (Table 1, Table 3). Mean $\mathrm{CC}(\%)$ varies between 32.9 and $37.2 \mathrm{CC} \%$, at which the samples VRR-1 and VRR-1-2 (same tree) reveal a range of $>20 \mathrm{CC} \%$, whereas the other PICE trees at VRR exhibit sizes between 13 and 16.3 CC \% (Table 5). Minimum values are around 20CC \% for VRR-1 (and 1-2) and around $30 \mathrm{CC} \%$ for all the other trees, and maximum values exceed $40 \mathrm{CC} \%$ with maximum values $>45 \mathrm{CC} \%$ (Table 5 ). Calculated correlation coefficients are almost all significant $(p<0.05)$ and are between 0.41 and 0.75 (Table 6). The arithmetic mean series for VRR-PICE displays an increase in mean $\mathrm{CC}(\%)$ of $>10 \mathrm{CC} \%$ in the common period (Fig. 3, bottom left).

The LADE tree-ring series at the same location, with a common growth period between 1865 and 2015 AD and MSL of 219 years, consist of 2 times 150 years, 190 and 385 years (Table 1, Table 3 ). Mean CC (\%) is between 26.3 and $36.0 \mathrm{CC} \%$ with minimum values ranging from 16.3 to $30.4 \mathrm{CC} \%$, whereas the maximum values per tree show a lower spread between 39.4 and $46.3 \mathrm{CC} \%$ (Table 5). As for PICE, LADE CC (\%) series reveal significant correlation coefficients among the individual trees (Table 6). The arithmetic mean series shows a decrease in $\mathrm{CC}(\%)$ of approximately 5 CC $\%$ in the period $1865-1980 \mathrm{AD}$, followed by a strong increase of more than $10 \mathrm{CC} \%$ during the last three decades (Fig. 3, bottom right).

The investigation of individual tree-ring $\mathrm{CC}(\%)$ series from three sampling sites (UAZR, FPCR, VRR) and two coniferous tree species (PICE, LADE) displays common variability of trees from the same species, independent of the sampling site. Individual CC (\%) per site and species show a general good agreement, represented in their correlation coefficients, which allows the establishment of arithmetic mean chronologies for their common growth periods (comparable time periods for all sites).

Common trends in the tree species, independent of the sampling site, indicate a common influence from environmental factors on $\mathrm{CC}(\%)$. All PICE series reveal a continuous increase of $\mathrm{CC}(\%)$ over time, whereas the LADE samples show a decrease over the common period that is replaced by a rapid increase over the past three decades (Fig. 4, left). The close relationship between the site series of the same tree species is also revealed by the calculated Pearson's correlation coefficient, where $r=0.86$ for LADE and $r=0.76$ for PICE mean series.

\subsection{Climate-cellulose relationships}

To test the influence of environmental conditions on CC (\%), Pearson's correlation coefficient is calculated between the mean CC (\%) series per site and species and the climate variables of temperature (cf. Fig. 4, right), precipitation, sunshine as well as cloud cover (Figs. 5-6, Figs. S1-S2 in the Supplement).

A temperature signal is clearly recorded in both tree species, independent of the sampling site (Fig. 5). Both PICE sites show significant correlations with temperature throughout the year, with high correlation during the growing season and, interestingly, in October $(r=0.67$ for UAZR-PICE, $r=0.65$ for VRR-PICE). Seasonal temperature averages result in the highest correlations for PICE; correlations for the summer season (JJA) result in $r=0.68-0.71$ and for autumn (SON) in $r=0.72-0.75$ for UAZR-PICE and VRRPICE, respectively. In LADE, correlations with temperature are lower than for PICE and significant correlations are found mostly during the growing season (May-August). Seasonal averages in temperature anomalies result in the highest correlations for the summer season (JJA) for both FPCR-LADE $(r=0.55)$ and VRR-LADE $(r=0.69)$.

Precipitation is best recorded in PICE at UAZR during the early growing season, revealing the highest correlation coefficients in May $(r=0.68)$. In contrast, LADE mean series at both sites and PICE at VRR mostly show non-significant correlations with precipitation records (Fig. 6).

The influence of cloud cover is the highest in PICE trees during the early growing season as well as towards the end (Fig. S1). Significant positive correlations are found in MAM for UAZR-PICE ( $r=0.49)$ and for JJA in both UAZR-PICE $(r=0.41)$ and VRR-PICE $(r=0.42)$. Interestingly, the cor- 
Table 5. General statistics of the individual $\alpha$-cellulose content series per tree from the modern sites. Given are the arithmetic mean values, the standard deviation, maximum and minimum $\alpha$-cellulose content values as well as the range per tree. To simplify the comparison between species, the species per site and tree individuum are enlisted once more.

\begin{tabular}{lllrrrrr}
\hline Site & $\begin{array}{l}\text { Sample } \\
\text { number }\end{array}$ & Species & $\begin{array}{r}\text { Mean } \\
\text { CC }(\%)\end{array}$ & $\begin{array}{r}\sigma \\
\text { CC }(\%)\end{array}$ & $\begin{array}{r}\text { Minimum } \\
\text { CC }(\%)\end{array}$ & $\begin{array}{r}\text { Maximum } \\
\text { CC }(\%)\end{array}$ & $\begin{array}{r}\text { Range } \\
\text { CC }(\%)\end{array}$ \\
\hline \multirow{2}{*}{ UAZR } & UAZR-1 & PICE & 33.2 & 3.9 & 26.7 & 42.6 & 15.9 \\
& UAZR-2 & PICE & 31.6 & 3.4 & 24.8 & 36.8 & 12.0 \\
& UAZR-3 & PICE & 38.6 & 1.6 & 34.8 & 42.8 & 8.0 \\
& UAZR-4 & PICE & 39.7 & 2.5 & 34.3 & 46.4 & 12.1 \\
\hline \multirow{2}{*}{ FPCR } & FPCR-1 & LADE & 29.0 & 6.5 & 18.3 & 48.9 & 30.6 \\
& FPCR-3 & LADE & 29.1 & 6.9 & 15.2 & 38.5 & 23.3 \\
& FPCR-5 & LADE & 32.9 & 6.7 & 20.9 & 51.6 & 30.7 \\
& FPCR-6 & LADE & 28.3 & 5.6 & 21.8 & 46.6 & 24.8 \\
\hline \multirow{2}{*}{ VRR } & VRR-1 & PICE & 32.9 & 5.2 & 21.2 & 41.9 & 20.7 \\
& VRR1-2 & PICE & 33.0 & 4.5 & 20.8 & 42.0 & 21.2 \\
& VRR-3 & PICE & 34.3 & 3.2 & 29.0 & 42.0 & 13.0 \\
& VRR-4 & PICE & 37.2 & 3.9 & 29.2 & 45.5 & 16.3 \\
& VRR-5 & PICE & 35.4 & 3.3 & 30.2 & 45.7 & 15.5 \\
\hline & VRR-6 & LADE & 30.6 & 5.4 & 19.9 & 39.5 & 19.6 \\
& VRR-7 & LADE & 36.0 & 4.4 & 30.4 & 44.5 & 14.1 \\
& VRR-8 & LADE & 26.3 & 6.0 & 16.3 & 39.4 & 23.1 \\
& VRR-9 & LADE & 32.5 & 5.5 & 26.4 & 46.3 & 19.9 \\
\hline
\end{tabular}

Table 6. Pearson's correlation coefficient calculated for the individual trees per site and species calculated in their common growth period (sample replication $\geq 4$ trees). Bold numbers indicate that correlations coefficients are significant $(p<0.05)$.

\begin{tabular}{|c|c|c|c|c|c|c|c|c|c|c|}
\hline & UAZR-1 & UAZR-2 & UAZR-3 & UAZR-4 & & & FPCR-1 & FPCR-3 & FPCR-5 & FPCR-6 \\
\hline UAZR-1 & 1 & & & & & FPCR-1 & 1 & & & \\
\hline UAZR-2 & -0.10 & 1 & & & & FPCR-3 & 0.31 & 1 & & \\
\hline UAZR-3 & 0.35 & 0.36 & 1 & & & FPCR-5 & 0.74 & 0.18 & 1 & \\
\hline \multirow[t]{2}{*}{ UAZR-4 } & 0.08 & 0.32 & 0.64 & 1 & & FPCR-6 & 0.79 & 0.39 & 0.67 & 1 \\
\hline & VRR-1 & VRR-1-2 & VRR-3 & VRR-4 & VRR-5 & & VRR-6 & VRR-7 & VRR-8 & VRR-9 \\
\hline VRR-1 & 1 & & & & & & & & & \\
\hline VRR-1-2 & 0.75 & 1 & & & & & & & & \\
\hline VRR-3 & 0.66 & 0.44 & 1 & & & & & & & \\
\hline VRR-4 & 0.75 & 0.62 & 0.63 & 1 & & & & & & \\
\hline VRR-5 & 0.75 & 0.41 & 0.70 & 0.68 & 1 & & & & & \\
\hline VRR-6 & & & & & & & 1 & & & \\
\hline VRR-7 & & & & & & & 0.78 & 1 & & \\
\hline VRR-8 & & & & & & & 0.35 & 0.54 & 1 & \\
\hline VRR-9 & & & & & & & 0.55 & 0.61 & 0.60 & 1 \\
\hline
\end{tabular}

relation coefficient for cloud cover and LADE mean series reveals significant negative correlations during the winter season (DJF; $r=-0.56$ for FPCR-LADE and $r=-0.63$ for VRR-LADE), especially in January for FPCR-LADE $(r=-0.57)$ and in February for VRR-LADE $(r=-0.46)$.

High, significant correlations with sunshine are observed for the late autumn and winter seasons, whereas negative correlations are found during summer season, being significant at both PICE sites in August, when VRR-PICE reveals sig- nificant negative correlations with sunshine from May to August (Fig. S2). For UAZR-PICE, the highest correlations with sunshine are found in January $(r=0.86)$ as well as in February $(r=0.76)$ and for the entire winter season (DJF, $r=$ 0.87), whereas for VRR-PICE, the highest correlations are found for November and December $(r=0.84$ and $r=0.82$, respectively) as well as for the winter season $(r=0.79)$. The pattern is similar for FPCR: significant positive correlations occur in late autumn and winter $(\mathrm{N}, \mathrm{D}, \mathrm{J}, \mathrm{F})$ and are highest in 
(a) Years before 2000

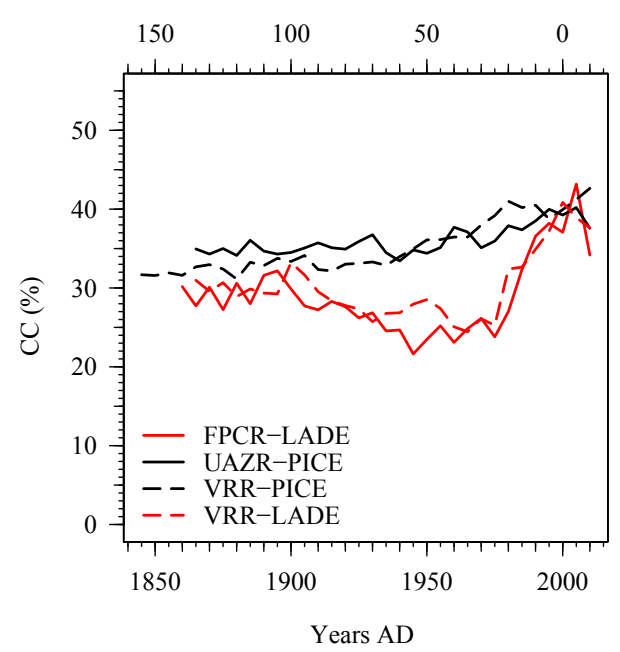

(b) Years before 2000

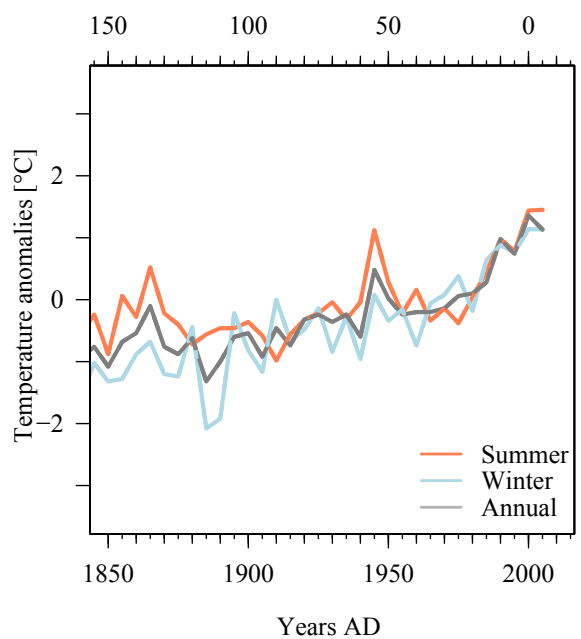

Figure 4. Modern cellulose content chronologies per site and species (a) and temperature anomalies shown for the NW and SW subregions within the Greater Alpine Region from HISTALP for summer (April-September) and winter (October-March) half-years and per year (b). The CC (\%) chronologies are calculated as arithmetic means from individual series for their common period (sample replication $\geq 4$ ). HISTALP data are given for the summer season (April-September), winter season (October-March) and annual anomalies calculated as 5 -year averages with respect to the sample resolution of CC (\%) series. Temperature anomalies for SW and NW subregions in the displayed season means are equal.

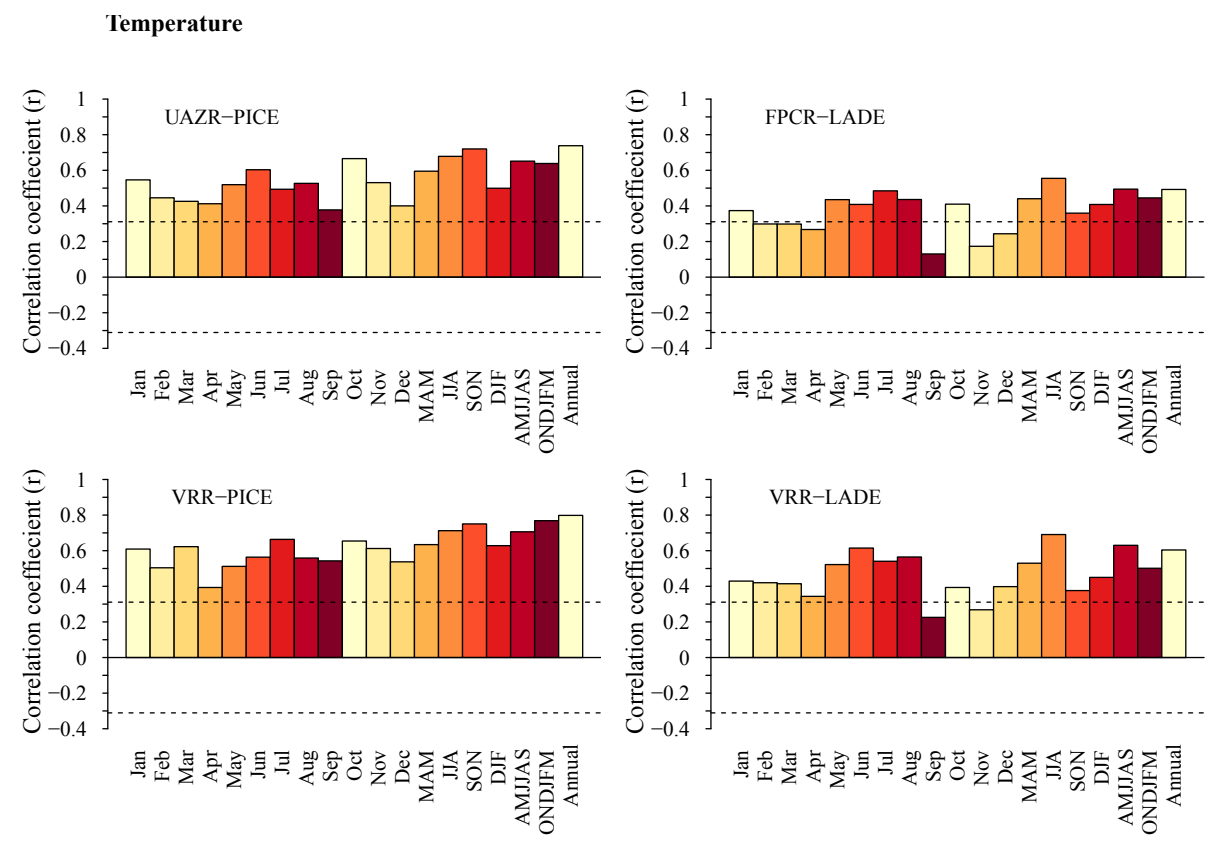

Figure 5. Pearson's correlation coefficient for mean CC (\%) and temperature anomalies (with reference to 1961-1990) for the period 18652005 AD. UAZR and FPCR are correlated with HISTALP NW region data, whereas VRR species are correlated with the SW region data set. The dashed horizontal lines indicate the level of significance $(p<0.05)$.

January $(r=0.62)$. In contrast, VRR-LADE shows the highest correlations in late autumn (November) and in February ( $r=0.66$ and $r=0.55$, respectively).

In summary, the results of the Pearson's correlation coefficient analysis between HISTALP data and mean CC $(\%)$ per species and site partly indicate a significant influence of environmental factors (temperature, precipitation, cloud cover, sunshine duration) on the $\mathrm{CC}(\%)$ in tree rings and the potential to reconstruct past climate from this novel supplementary proxy. However, the comparison of the two conifer- 
Precipitation
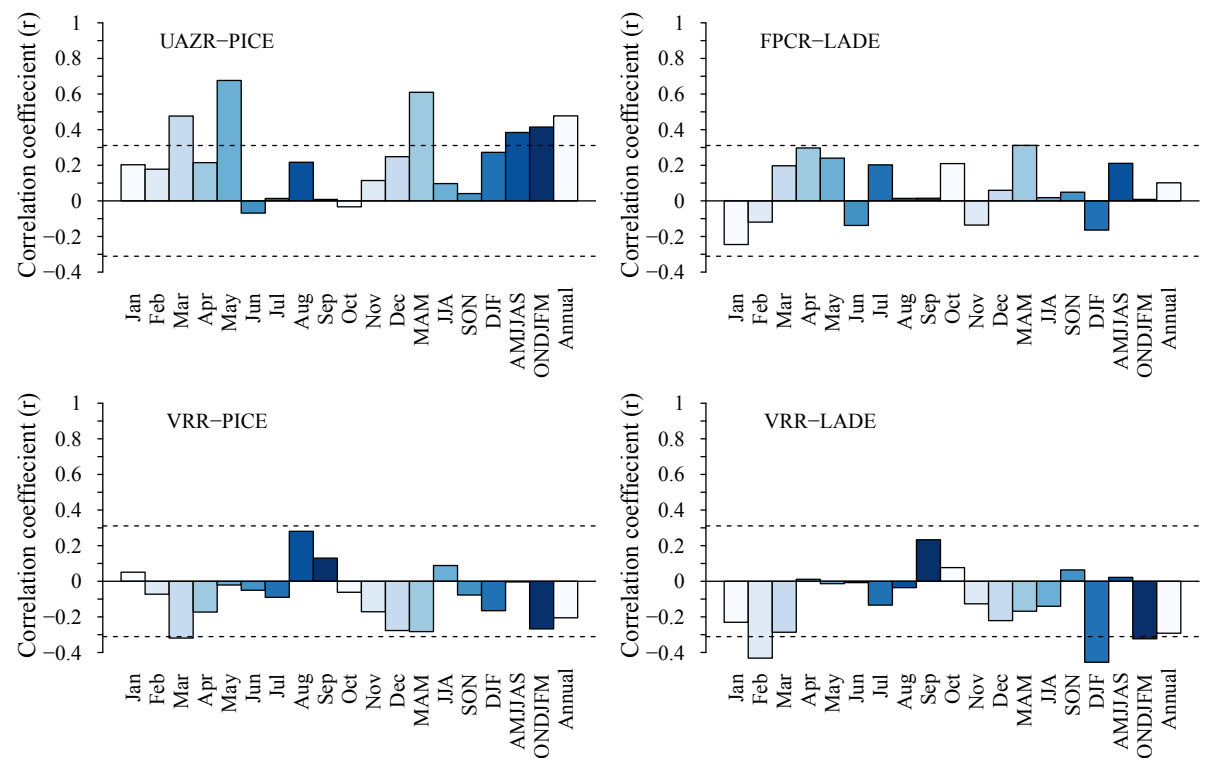

Figure 6. Pearson's correlation coefficient for mean CC (\%) and temperature anomalies (with reference to 1961-1990) for the period 18652005 AD. UAZR and FPCR are correlated with HISTALP NW region data, whereas VRR species are correlated with the SW region data set. The dashed horizontal lines indicate the level of significance $(p<0.05)$.

ous species further indicates a species-specific response from $\mathrm{CC}(\%)$ to the environmental conditions.

\subsection{Holocene CC (\%) series}

In a further step, $\mathrm{CC}(\%)$ series are established for LADE and PICE tree-ring samples from glacier forefields, peat bogs and small lakes for the period from 8550 to 3500 years b2k (Fig. 7). To investigate trends in the $\mathrm{CC}(\%)$, the individual series are averaged per species (PICE in blue, LADE in green), and an arithmetic mean is also calculated over all series (black), which is smoothed by a spline (orange) to illustrate long-term changes (Fig. 7). The arithmetic mean series shows the high variability in the $\mathrm{CC}(\%)$ over time, fluctuating between 22 and $40 \mathrm{CC} \%$. Further, the series exhibits interesting low-frequency trends with rapidly decreasing $\mathrm{CC}(\%)$ in the periods $8250-7950$ years b2k $(\triangle \mathrm{CC}(\%)$ $\sim 5 \mathrm{CC} \%), 6250-5950$ years b2k $(\Delta \mathrm{CC}(\%) \sim 2 \mathrm{CC} \%)$, 5650-5450 years b2k $(\Delta \mathrm{CC}(\%) \sim 4 \mathrm{CC} \%), 5300-5000$ years b2k $(\triangle \mathrm{CC}(\%) \sim 5.5 \mathrm{CC} \%)$ and $4500-4000$ years b2k $(\triangle \mathrm{CC}(\%) \sim 6 \mathrm{CC} \%)$. Besides these phases of rapid decreases, $\mathrm{CC}(\%)$ is increasing on a multi-centennial scale between 7350 and 6250 years b2k ( $\triangle \mathrm{CC}(\%) \sim 4.5 \mathrm{CC} \%)$ and more rapidly after low $\mathrm{CC}(\%)$ phases, e.g. in the periods $7950-7750$ years b2k ( $\triangle \mathrm{CC}(\%) \sim 3.5 \mathrm{CC} \%), 5450$ 5300 years b2k $(\triangle \mathrm{CC}(\%) \sim 7 \mathrm{CC} \%)$ and $4000-3650$ years b2k $(\Delta \mathrm{CC}(\%) \sim 8.5 \mathrm{CC} \%)$. The calculated arithmetic mean series per species exhibit mostly lower mean values in the LADE series (green) and more positive values for PICE (blue). LADE shows extremely low CC (\%) between 4700 and 4200 years b2k, and extremely high values between 4000 and 3900 years b2k. The PICE average series shows extremely low values around 8000 years b2k as well as around 4000 years b2k; otherwise both the LADE and PICE series mostly fluctuate between 30 and $40 \mathrm{CC} \%$.

For most of the investigated time period, the sample replication amounts to three trees, two gaps at 7300 and 6300 years $\mathrm{b} 2 \mathrm{k}$ are solely covered by a single tree and a replication of $\geq 4$ trees is partly achieved (Fig. 7, bottom).

Figure 7 further displays identified cold phases (light-blue bars) analysed by Wanner et al. (2011), where the darker bars illustrate the cold phases which were identified by three different phenomena (cold phases, glacier advances, Bond cycles) and the lighter areas mark the entire length of the cold phases; additional cold periods are marked as blue vertical lines (Wanner et al., 2011, 2015). Interestingly, the strong decreases in cellulose content emerge mostly after the indicated cold phases.

As modern wood samples already displayed differential trends in the CC (\%), mean series of LADE and PICE and their low-frequency trends are investigated more closely in Fig. S3, where the contribution of individual trees per species is revealed in the sample replication (Fig. S3d). The mean series reveal distinct offsets over time (Fig. S3a). In the periods $8100-7800$ years b2k and $5600-4600$ years b2k, the smoothed values exhibit a common long-term trend, whereas in the remnant phases, the series even show opposed trends. The difference between the two arithmetic mean series em- 


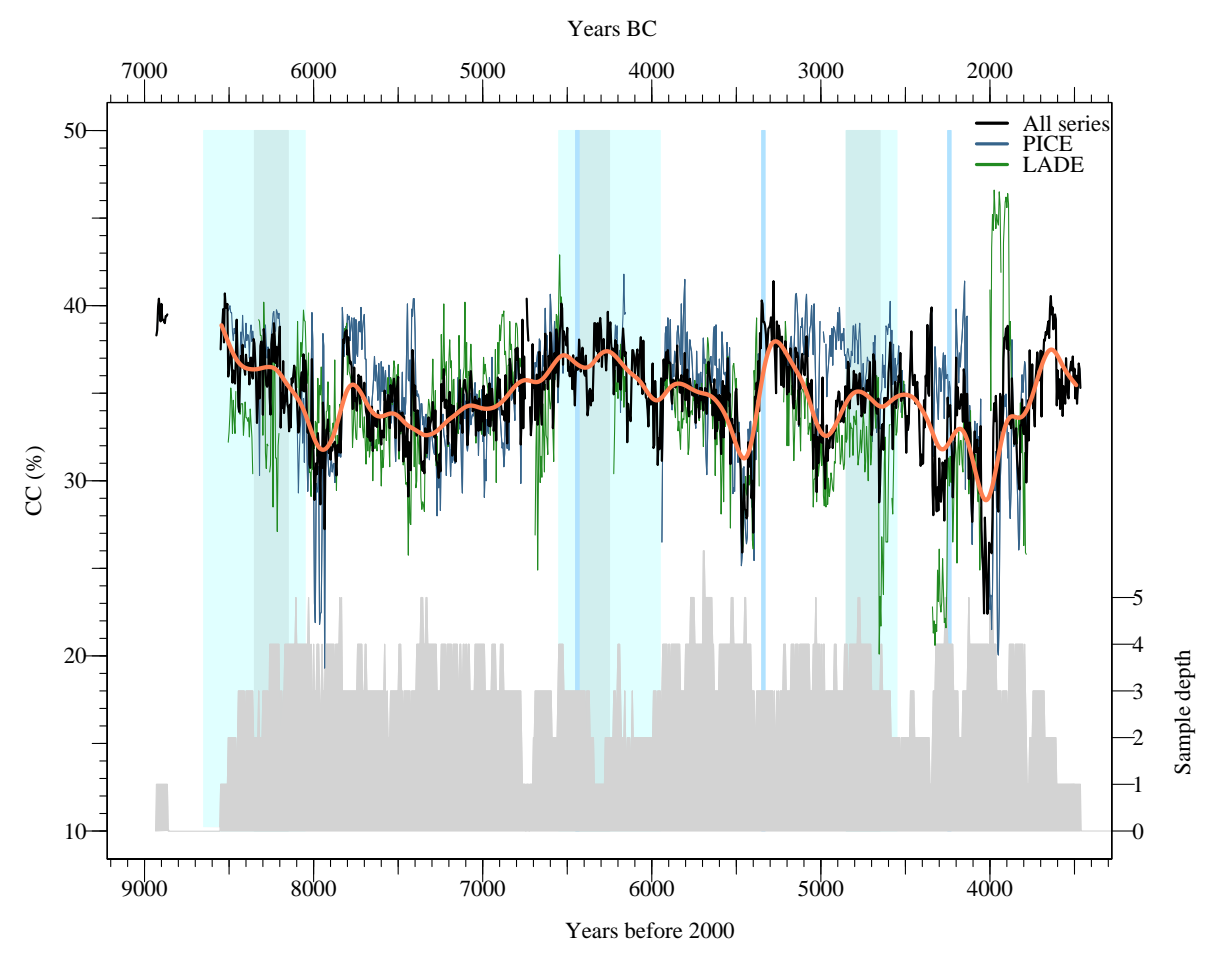

Figure 7. Progression of mean cellulose content during the time period 9000 to 3500 years b2k. Mean cellulose content is calculated for the two species Larix decidua Mill. (LADE, green line) and Pinus cembra L. (PICE, grey line); the overall mean series is shown in black and its smoothed values in orange. The sample depth is on the right side (grey polygon). Major cold phases are indicated as cyan rectangles, where darker colours implicit the cold events and the lighter colours their entire duration (Wanner et al., 2011). Additional cold events are marked as blue vertical lines (Wanner et al., 2015).

phasises that the differences between the species are not constant over time (Fig. S3b).

Although the Holocene samples stem from various sites, the phases $8900-8200$ years b2k and 7500-6700 years b2k are dominated by glacier forefield sites at Mont Miné and Tschierva glacier, respectively (Fig. S3c). For both intervals, the two coniferous species are present, and as the sampling site is equal, similar as well as divergent trends in the species result, presumably from the impact of environmental factors on $\mathrm{CC}(\%)$.

In order to also confirm the non-existing influence of the sampling site location on CC (\%) series in Holocene samples, the arithmetic mean of $\mathrm{CC}(\%)$ per site and species is calculated and compared to latitude, longitude and elevation of the individual sites (Fig. S4). Calculated linear regressions (dotted lines) per species do not indicate a dependence on $\mathrm{CC}(\%)$ and sampling site locations, as linear regressions are non-significant $(p>0.05)$.

To further exclude non-climatic influences on $\mathrm{CC}(\%)$, individual CC (\%) series per tree are aligned according to their biological age by taking the estimated pith-offset into account (Fig. S5). Both PICE (upper panel) and LADE (lower panel) do not reveal any distinct low-frequency trends in the age-aligned series.

\section{Discussion}

The determination of $\mathrm{CC}(\%)$ is a common procedure in treering laboratories that measure stable-isotope ratios in treering cellulose. However, to our current knowledge, existing records of $\mathrm{CC}(\%)$ were simply used as a tool to ascertain the quality of the extracted cellulose; the CC (\%) is, if mentioned in the literature, given as a mean value and its temporal variability is not regarded any further.

The investigation of $\mathrm{CC}(\%)$ in modern tree samples of two high-Alpine coniferous species (LADE, PICE) at three sites in the Swiss Alps reveals common variations within the tree species, independent of the sampling site, and points out a common environmental driver. While PICE trees show a continuous increase over the investigated common period, LADE trees are characterised by a decrease throughout the 20 th century followed by a strong increase in $\mathrm{CC}(\%)$ from the 1980 s to today.

In order to exclude any age-related biases, possible age trends in $\mathrm{CC}(\%)$ series have been investigated, even though they were not expected as the trends in modern $\mathrm{CC}(\%)$ series of the two tree species diverge and do not reveal a common increase or decrease over time. The age alignment of both modern and Holocene CC (\%) series by their biologi- 
cal age, taking their estimated pith-offset (PO) into account, illustrates that $\mathrm{CC}(\%)$ series are not biased by age trends, which leads us to the conclusion that the trends which we find in $\mathrm{CC}(\%)$ series are most probably driven by climatic variables (Fig. S5).

Further, the two different species Larix decidua Mill. and Pinus cembra L. at the sampling site Val Roseg (VRR) exhibit different trends in their mean chronologies. As they experience the same climate, the role of the biological factors here is undoubted. This is rather obvious as the two coniferous species are compared: Larix decidua Mill. is a deciduous species, whereas Pinus cembra L. is an evergreen species. Therefore, differences in their metabolism are to be expected. Although the two species are found at the upper treeline and known to be adapted to the harsh environmental conditions, LADE is characterised as a light-demanding pioneer species which is often found in open settings, e.g. on glacier forefields, whereas PICE is, under undisturbed conditions, the highest rising species in the inner sections of the Alps and therefore adapted to short vegetation periods (Ellenberg, 1996). The fact that individual CC (\%) series from the same species at different sites are similar calls for a common driving factor of regional extent, such as temperature.

The investigation of the climate-cellulose relationships by correlating mean $\mathrm{CC}(\%)$ series with climate variables (temperature, precipitation, cloud cover, sunshine duration) extracted from the HISTALP database (Auer et al., 2007) over a common period of 140 years (1865-2008 AD; 1880-2008 for sunshine) reveals interesting correlation coefficients between CC (\%) and climate. Temperature is recorded in both species, revealing the highest correlations during the summer season, and additionally for the autumn season in PICE trees. An increase in CC (\%) in trees with increasing temperature may be explained by the enhanced sink activity in trees at the upper treeline. In the attempt to establish a functional explanation of the Alpine treeline, Körner (1998) compiled five hypotheses in which the climate-driven treeline is either driven by stress, disturbance, reproduction, carbon balance or growth limitation (Körner, 1998). Since then, several publications have shown that concentrations of non-structural carbon (NSC) in trees at the upper treeline increase with elevation, thereby indicating no evidence that trees at high elevations experience a carbon shortage but rather implying a lowered sink activity at the upper treeline resulting in a growth-limitation (Hoch et al., 2002; Hoch and Körner, 2009, 2012; Körner, 2003). As photosynthetic activity is less sensitive to low temperatures than growth, it may still be active at $0{ }^{\circ} \mathrm{C}$, at which temperatures are too low for tree growth (minimum temperatures for tree growth are $\sim 5-7^{\circ} \mathrm{C}$ ) (Hoch and Körner, 2012; Körner, 1998; Tranquilini, 1979). Therefore, the carbon acquisition in a tree can still be active, although low temperatures prevent tissue formation. As a consequence, the concentration of NSC in trees at the upper treeline is increasing, as the source is still active, but the sink is not. In conclusion, lower temperatures during the growing season reduce the tissue formation in tree rings, resulting in less $\mathrm{CC}(\%)$ in the tree ring as the source activity is low. Regarding the investigated species in this study, the LADE as a pioneer species that explores the upper treeline greatly benefits from the increase in temperature associated with global warming and which has been especially pronounced since the 1980s (Rebetez and Reinhard, 2008). As temperatures during the growing season increase and the growing season is potentially prolonged, the sink activity and the $\mathrm{CC}(\%)$ in tree rings increase. This might explain the correlations found with winter temperatures, especially for PICE trees, i.e. potential photosynthetic activity at low temperatures in winter when tissue formation is no longer possible (Hoch et al., 2002 and references therein). Thereby, the concentration of NSC is increasing and is already available for tissue formation as soon as temperatures allow for it. Future studies on CC (\%) on an annual and even intra-annual resolution could help to improve our understanding of the influence of winter temperatures on the $\mathrm{CC}(\%)$ in tree rings.

In PICE trees, the CC (\%) slowly and steadily increases over time, potentially reacting more slowly to increased temperatures, prolonged growing seasons and rising mean annual temperatures. In contrast, LADE series from modern trees exhibit a rapid increase over the past 30 years, obviously benefitting from increased temperatures during the growing season. The CC (\%) in Holocene wood remains and modern wood samples could therefore serve as a novel additional proxy in multi-proxy approaches, offering the opportunity to test the temperature sensitivity of diverse tree species, before combining them into chronologies. A combination of differently reacting tree species allows a complementation of temperature-CC $(\%)$ relationships, which may result in more robust climate reconstructions.

Moreover, the PICE trees at two modern sampling sites showed highly significant correlation coefficients with sunshine duration especially during the winter season. As evergreen conifers are known to be photosynthetically active throughout the year as long as temperatures permit photosynthetic activity (Hoch et al., 2002 and references therein), PICE trees may potentially benefit from increased sunshine duration and be able to increase the carbon acquisition during the winter season. Therefore, the CC (\%) in PICE trees may even represent an annual signal. On the other hand, significant correlations found for sunshine duration and cloud cover with LADE CC (\%) series may represent artefacts, as LADE trees lose their needles in autumn and carbon acquisition is only possible during the growing season.

As the framework of the project AHTRIR included analyses of both living and subfossil wood, Holocene wood remains were also investigated for signs of degradation. Most samples were well-preserved, and for the period from 9000 to 3500 years $\mathrm{b} 2 \mathrm{k}$, the $\mathrm{CC}(\%)$ also varied between 30 and $40 \mathrm{CC} \%$. Therefore, the CC (\%) in living and subfossil wood samples is comparable. Only a small number of outliers were found (see also Sect. 2.6), where CC (\%) values showed pro- 
nounced decreases, mostly appearing in the outermost rings as well as along cracks in the wooden material. We assume that these tree-ring sections have been affected by weathering and therefore reveal a high degree of degradation, whereas the other rings have been well preserved (Fig. S6). Although the potential degradation of subfossil wood might have an impact, $\mathrm{CC}(\%)$ of modern and subfossil wood is comparable despite a few outliers, which leads to the conclusion that long-term variations in Holocene $\mathrm{CC}(\%)$ could serve as an indicator of climate variations. Moreover, there is no trend detected in $\mathrm{CC}(\%)$ over time (i.e. towards the past) which would be expected if degradation was a major driver of $\mathrm{CC}(\%)$ variations.

The low-frequency trends exhibited in the mean series of Holocene CC (\%) in the period from 9000 to 3500 years b2k illustrate the potential of $\mathrm{CC}(\%)$ as an additional proxy. The arithmetic mean $\mathrm{CC}(\%)$ series shows pronounced decreases after known cold events in the Early and mid-Holocene, whereas a continuous increase is observed between 7350 and 6250 years b2k, which could be the result of increased temperatures and more favourable growing conditions for trees at the upper treeline. However, the investigations of individual species also illustrate differences in variation between LADE and PICE, approving the observed differences in species within modern samples. A complete understanding of $\mathrm{CC}(\%)$ variations in different tree species and the influence of environmental conditions on CC (\%) will help to further improve the robustness of this novel proxy.

The presented study could benefit from the framework of the project in which it was performed, but was at the same time limited by it: the vast advantage of the presented study is thousands of individual cellulose samples from both living and subfossil wood material distributed over large parts of the Holocene, which allowed the investigation of their CC (\%) and served as a testbed for the temporal study of CC (\%) in tree rings. However, we were at the same time limited by the high number of samples, which so far has not allowed for an analysis of replicates within this project. Further, the high-Alpine tree species used in this project often reveal very narrow rings and the amount of extracted $\alpha$-cellulose was just sufficient for further analysis. As the initial aims of the project did not include the closer analysis of $\mathrm{CC}(\%)$ and its variation but was rather a concept that developed during the progress of the project, the sampling and analysis of replicates has not been conducted so far. Yet, in a study performed earlier from the Lötschental in Switzerland, we evaluated the natural variability of $\mathrm{CC}(\%)$ on different LADE tree-ring cores over time (Figs. S7, S8). It documents a mean standard deviation of $3.7 \%$ in $\mathrm{CC}(\%)$ for five individual cores from different trees of the same location. This standard deviation would even be significantly smaller if the values of the different cores were adjusted according to their mean values. Therefore, we are confident that replicates of LADE samples of the present study would be the same within a few couple of percent (approx. 3 to $4 \%$ ). In the current study, first mea- sures to minimise and quantify the error of $\mathrm{CC}(\%)$ have been presented; however, in future studies, it will be essential to accomplish a robust error estimation by a replicate sampling of the same tree.

\section{Conclusion and outlook}

For the first time, $\mathrm{CC}(\%)$ and its temporal variability of the two coniferous Alpine treeline species Larix decidua Mill. (European larch, deciduous) and Pinus cembra L. (Swiss stone pine, evergreen) have been investigated on a centennial scale for modern samples from living trees and on a multimillennial scale for the Early and mid-Holocene including the transition to the Late Holocene. The established CC (\%) series revealed species-specific long-term trends, independent of the location of the sampling site along the Swiss Alps in both past and present tree samples. First investigations of climate-cellulose relationships display the ability of CC (\%) to record temperature at the Alpine treeline.

As higher CC $(\%)$ values have been observed for lowelevation tree-ring material (unpublished data), the influence of elevation ought to be examined along an altitudinal gradient to quantify the decrease in $\alpha$-cellulose and thereby verify the hypothesis that not carbon, but temperature is the limiting factor, resulting in limited sink activity which results in turn in lower CC $(\%)$ values. This goes along the line of nonstructural carbon investigations.

In a succeeding study, the site and species sensitivity of multiple proxies (TRW, $\mathrm{CC}(\%), \delta \mathrm{D}, \delta^{13} \mathrm{C}, \delta^{18} \mathrm{O}$ ) and the correlations between the individual proxies will be examined in relation to the environmental conditions per site to quantify their ability for multi-millennial reconstructions based on a multi-proxy approach from tree rings (Ziehmer et al., 2018). Thereby, the effects of variations in CC (\%) on triple isotope records will be tested.

Moreover, CC $(\%)$ series ought to be established in annual resolution to establish a robust calibration and verification of the $\mathrm{CC}(\%)$-climate relationship as the reduced resolution of our samples (5-year tree-ring blocks) prohibits the proper analysis of the climatic response of cellulose and a robust calibration against instrumental data. The existence of numberless $\mathrm{CC}(\%)$ series in dendro-laboratories all over the world will allow a broad investigation of $\mathrm{CC}(\%)$ in various species from widespread sampling sites in temporal resolution, reaching from intra-annual to decadal tree-ring samples.

A future interlaboratory comparison comparable to the study by Boettger et al. (2007) could confirm the comparability of $\alpha$-cellulose series between individual laboratories. Such a comparison should also include investigations on the influence of preparation methods (milling vs. cutting wood), the individual steps and duration of the extraction, the role of the sample size, as well as the influence of tree species, juvenile vs. mature tree rings, and heartwood vs. sapwood. Further, purity of the extracted $\alpha$-cellulose can be checked by 
FTIR spectra (Galia, 2015). Such an interlaboratory comparison is essential and a prerequisite for the assessment of the accuracy of $\mathrm{CC}(\%)$ and comparison of $\mathrm{CC}(\%)$ series among different tree-ring laboratories.

Further, the analysis of a relationship between $\mathrm{CC}(\%)$ and wood density would be highly interesting. These two proxies are usually not investigated within the same research project. However, establishing a link between these two variables might allow conclusions to be drawn on wood density by determining the $\mathrm{CC}(\%)$ and vice versa. Hence, further research on the relationship between $\mathrm{CC}(\%)$ and other tree-ring proxies (tree-ring width, maximum latewood density, stable isotopes) is essential. Although evaluating $\mathrm{CC}(\%)$ is obviously not easier than measuring tree-ring width, there is the significant potential to use it as an additional supplementary proxy, especially in those cases in which CC (\%) series are already existent in tree-ring laboratories and climate is to be reconstructed in a multi-proxy approach.

A complete comprehension of environmental factors controlling the $\mathrm{CC}(\%)$ in diverse tree species will result in an improved understanding of physiological and biochemical processes in forming annual growth layers, and thus serve as an additional proxy in dendroclimatology. This study represents a first step in this direction and intends to motivate other treering researchers in the field of dendroclimatology and stableisotope analysis to investigate their existing $\mathrm{CC}(\%)$ series and to carry out further research on these data.

Data availability. At present, data can be obtained upon request. As agreed among the project participants, data sets will be made available to the public after the official completion of the Alpine Holocene Tree Ring Isotope Records (AHTRIR) project.

Supplement. The supplement related to this article is available online at: https://doi.org/10.5194/bg-15-1047-2018-supplement.

Author contributions. MMZ and ML designed the study. The subfossil wood sampling was mainly done by $\mathrm{KN}$ and $\mathrm{CS}$, whereas the living wood sampling was performed by all authors. The preparation of the experiments as well as the statistical analysis and interpretation were carried out by MMZ. The drafting of the manuscript was accomplished by MMZ with contributions from all co-authors.

Competing interests. The authors declare that they have no conflict of interest.

Acknowledgements. We thank Andrea Thurner and Andreas Oesterreicher from the Alpine Tree-Ring Group at the University of Innsbruck for the sample preparation. Further thanks go to Jonathan Lamprecht, Yannick Rohrer, Igor Zelenovic, Regula Mülchi and Martina Messmer for assistance during sample preparation. Many thanks go to Peter Nyfeler for technical support and experience.

The project is funded by the Swiss National Science Foundation (SNSF, 2000212_144255) and the Austrian Science Fund (FWF, grant I-1183-N19) and is supported by the Oeschger Center for Climate Change Research, University of Bern, Bern, Switzerland (OCCR).

Edited by: David Gillikin

Reviewed by: two anonymous referees

\section{References}

Anhäuser, T., Greule, M., Polag, D., Bowen, G. J., and Keppler, F.: Mean annual temperatures of mid-latitude regions derived from $\delta 2 \mathrm{H}$ values of wood lignin methoxyl groups and its implications for paleoclimate studies, Sci. Total Environ., 574, 1276-1282, https://doi.org/10.1016/j.scitotenv.2016.07.189, 2017.

Auer, I., Reinhard, B., Jurkovic, A., Lipa, W., Orlik, A., Potzmann, R., Sch, W., Ungersb, M., Matulla, C., Briffa, K., Jones, P., Efthymiadis, D., Brunetti, M., Nanni, T., Maugeri, M., Mercalli, L., Mestre, O., Moisselin, J., Begert, M., and Gerhard, M.: HISTALP - historical instrumental climatological surface time series of the Greater Alpine Region, 46, 17-46, https://doi.org/10.1002/joc.1377, 2007.

Boettger, T., Haupt, M., Knller, K., Weise, S. M., Waterhouse, J. S., Rinne, T., Loader, N. J., Sonninen, E., Jungner, H., Masson-delmotte, V., Guillemin, M., Pierre, M., Pazdur, A., Leuenberger, M., Filot, M., Saurer, M., Reynolds, C. E., Helle, G., and Schleser, G. H.: Wood Cellulose Preparation Methods and Mass Spectrometric Analyses of $\delta^{13} \mathrm{C}, \delta^{18} \mathrm{O}$, and Nonexchangeable $\delta^{2} \mathrm{H}$ Values in Cellulose, Sugar, and Starch: An Interlaboratory Comparison, Sug, Anal. Chem., 79, 4603-4612, https://doi.org/10.1021/ac0700023, 2007.

Borella, S., Leuenberger, M., Saurer, M., and Siegwolf, R.: C analysis of tree rings: Pooling, milling, and cellulose extraction, J. Geophys. Res., 103, 19519, https://doi.org/10.1029/98JD01169, 1998.

Borella, S., Leuenberger, M., and Saurer, M.: O in tree rings: Woodcellulose comparison and method dependent sensitivity, J. Geophys. Res., 104, 19267, https://doi.org/10.1029/1999JD900298, 1999.

Brenninkmeijer, C. A. M.: Deuterium, oxygen-18 and carbon-13 in tree rings and peat deposits in relation to climate, $\mathrm{PhD}$ thesis, University of Groningen, the Netherlands, 1983.

Büntgen, U., Frank, D. C., Nievergelt, D., and Esper, J.: Summer temperature variations in the European Alps, AD 755-2004, J. Clim., 19, 5606-5623, https://doi.org/10.1175/JCLI3917.1, 2006.

Büntgen, U., Tegel, W., Nicolussi, K., McCormick, M., Frank, D., Trouet, V., Kaplan, J. O., Herzig, F., Heussner, K.-U., Wanner, H., Luterbacher, J., and Esper, J.: 2500 years of European climate variability and human susceptibility, Science, 331, 578582, https://doi.org/10.1126/science.1197175, 2011.

Burton, J. O. and Rasch, R. H.: The determination of the alphacellulose content and copper number of paper, Bur. Stand. J. Res., 6, 603, https://doi.org/10.6028/jres.006.037, 1931. 
Cross, C. F. and Bevan, E. J.: Researches on cellulose III (1901910), Longmans, Green, and Company, London, 1912.

Cullen, L. E. and Macfarlane, C.: Comparison of cellulose extraction methods for analysis of stable-isotope ratios of carbon and oxygen in plant material, Tree Physiol., 25, 563-569, https://doi.org/10.1093/treephys/25.5.563, 2005.

Ellenberg, H.: Vegetation Mitteleuropas mit den Alpen in ökologischer, dynamischer und historischer Sicht, Ulmer, Stuttgart, 1996.

Esper, J., Cook, E. R., and Schweingruber, F. H.: Lowfrequency signals in long tree-ring chronologies for reconstructing past temperature variability, Science, 295, 2250-2253, https://doi.org/10.1126/science.1066208, 2002.

Filot, M. S., Leuenberger, M., Pazdur, A., and Boettger, T.: Rapid online equilibration method to determine the $\mathrm{D} / \mathrm{H}$ ratios of non-exchangeable hydrogen in cellulose, Rapid Commun. Mass Spectrom., 20, 3337-3344, https://doi.org/10.1002/rcm.2743, 2006.

Frank, D. C., Poulter, B., Saurer, M., Esper, J., Huntingford, C., Helle, G., Treydte, K., Zimmermann, N. E., Schleser, G. H., and Ahlström, A.: Water-use efficiency and transpiration across European forests during the Anthropocene, Nat. Clim. Chang., 5, 579-583, 2015.

Freudenberg, K.: Lignin: Its Constitution and Formation from p-Hydroxycinnamyl Alcohols: Lignin is duplicated by dehydrogenation of these alcohols; intermediates explain formation and structure, Science, 148, 595-600, https://doi.org/10.1126/science.148.3670.595, 1965.

Galia, A., Schiavo, B., Antonetti, C., Galletti, A. M. R., Interrante, L., Lessi, M., Scialdone, O., and Valenti, M. G.: Autohydrolysis pretreatment of Arundo donax: a comparison between microwave-assisted batch and fast heating rate flowthrough reaction systems, Biotechnology for Biofuels, 8, 1-18 https://doi.org/10.1186/s13068-015-0398-5, 2015.

Gaudinski, J. B., Dawson, T. E., Quideau, S., Schuur, E., Roden, J. S., Trumbore, S. E., Sandquist, D. R., Oh, S.W., and Wasylishen, R. E.: Comparative Analysis of Cellulose Preparation Techniques for Use with ${ }^{13} \mathrm{C},{ }^{14} \mathrm{C}$, and ${ }^{18} \mathrm{O}$ Isotopic Measurements, Anal. Chem., 77, 7212-7224, https://doi.org/10.1021/ac050548u, 2005.

Genet, M., Li, M., Luo, T., Fourcaud, T., Clément-Vidal, A., and Stokes, A.: Linking carbon supply to root cell-wall chemistry and mechanics at high altitudes in Abies georgei, Ann. Bot., 107, 311-320, https://doi.org/10.1093/aob/mcq237, 2011.

Gindl, W., Grabner, M., and Wimmer, R.: The influence of temperature on latewood lignin content in treeline Norway spruce compared with maximum density and ring width, Trees - Struct. Funct., 14, 409-414, https://doi.org/10.1007/s004680000057, 2000.

Haigler, C. H., Ivanova-Datcheva, M., Hogan, P. S., Salnikov, V. V, Hwang, S., Martin, K., and Delmer, D. P.: Carbon partitioning to cellulose synthesis, Plant Mol. Biol., 47, 29-51, https://doi.org/10.1023/A:1010615027986, 2001.

Hales, T. C., Ford, C. R., Hwang, T., Vose, J. M., and Band, L. E.: Topographic and ecologic controls on root reinforcement, J. Geophys. Res.-Solid Earth, 114, 1-17, https://doi.org/10.1029/2008JF001168, 2009.

Hoch, G. and Körner, C.: The carbon charging of pines at the climatic treeline: a global comparison, Oecologia, 135, 10-21, https://doi.org/10.1007/s00442-002-1154-7, 2003.
Hoch, G. and Körner, C.: Growth and carbon relations of tree line forming conifers at constant vs. variable low temperatures, J. Ecol., 97, 57-66, https://doi.org/10.1111/j.13652745.2008.01447.x, 2009.

Hoch, G. and Körner, C.: Global patterns of mobile carbon stores in trees at the high-elevation tree line, Glob. Ecol. Biogeogr., 21, 861-871, https://doi.org/10.1111/j.1466-8238.2011.00731.x, 2012.

Hoch, G., Popp, M., and Körner, C.: Altitudinal increase of mobile carbon pools in Pinus cembra suggests sink limitation of growth at the Swiss treeline, Oikos, 98, 361-374, https://doi.org/10.1034/j.1600-0706.2002.980301.x, 2002.

Hu, W. J., Harding, S. A, Lung, J., Popko, J. L., Ralph, J., Stokke, D. D., Tsai, C. J., and Chiang, V. L.: Repression of lignin biosynthesis promotes cellulose accumulation and growth in transgenic trees, Nat. Biotechnol., 17, 808-812, https://doi.org/10.1038/11758, 1999.

Joerin, U. E., Stocker, T. F., and Schlüchter, C.: Multicentury glacier fluctuations in the Swiss Alps during the Holocene, The Holocene, 16, 697-704, https://doi.org/10.1191/0959683606h1964rp, 2006.

Joerin, U. E., Nicolussi, K., Fischer, A., Stocker, T. F., and Schlüchter, C.: Holocene optimum events inferred from subglacial sediments at Tschierva Glacier, Eastern Swiss Alps, Quaternary Sci. Rev., 27, 337-350, https://doi.org/10.1016/j.quascirev.2007.10.016, 2008.

Kahmen, A., Dawson, T. E., Vieth, A., and Sachse, D.: Leaf wax n-alkane $\delta \mathrm{D}$ values are determined early in the ontogeny of Populus trichocarpa leaves when grown under controlled environmental conditions, Plant, Cell Environ., 34, 1639-1651, https://doi.org/10.1111/j.1365-3040.2011.02360.x, 2011.

Keel, S. G., Joos, F., Spahni, R., Saurer, M., Weigt, R. B., and Klesse, S.: Simulating oxygen isotope ratios in tree ring cellulose using a dynamic global vegetation model, Biogeosciences, 13, 3869-3886, https://doi.org/10.5194/bg-13-3869-2016, 2016.

Keller, K. M., Lienert, S., Bozbiyik, A., Stocker, T. F., Churakova (Sidorova), O. V., Frank, D. C., Klesse, S., Koven, C. D., Leuenberger, M., Riley, W. J., Saurer, M., Siegwolf, R., Weigt, R. B., and Joos, F.: 20th century changes in carbon isotopes and water-use efficiency: tree-ring-based evaluation of the CLM4.5 and LPX-Bern models, Biogeosciences, 14, 26412673, https://doi.org/10.5194/bg-14-2641-2017, 2017.

Kimak, A., Kern, Z., and Leuenberger, M.: Qualitative Distinction of Autotrophic and Heterotrophic Processes at the Leaf Level by Means of Triple Stable Isotope (C-O-H) Patterns, Front. Plant Sci., 6, 1008, https://doi.org/10.3389/fpls.2015.01008, 2015.

Körner, C.: A re-assessment of high elevation treeline psoitions and their explanation, Oecologia, 115, 445-459, 1998.

Körner, C.: Carbon limitation in trees, J. Ecol., 91, 4-17, https://doi.org/10.1046/j.1365-2745.2003.00742.x, 2003.

Laumer, W., Andreu, L., Helle, G., Schleser, G. H., Wieloch, T., and Wissel, H.: A novel approach for the homogenization of cellulose to use micro-amounts for stable isotope analysis, Rapid Commun. Mass Spectrom., 23, 1934-1940, 2009.

Leavitt, S. W. and Danzer, S. R.: Method for batch processing small wood samples to holocellulose for stable-carbon isotope analysis, Anal. Chem., 65, 87-89, https://doi.org/10.1021/ac00049a017, 1993. 
Leuenberger, M.: Stable isotopes in tree rings as climate and stress indicators, vdf Hochschulverlag AG, 1998.

Ljungqvist, F. C., Krusic, P. J., Sundqvist, H. S., Zorita, E., Brattström, G., and Frank, D.: Northern Hemisphere hydroclimate variability over the past twelve centuries, Nature, 532, 9498, https://doi.org/10.1038/nature17418, 2016.

Loader, N. J., Robertson, I., Barker, A. C., Switsur, V. R., and Waterhouse, J. S.: An improved technique for the batch processing of small wholewood samples to $\alpha$-cellulose, Chem. Geol., 136, 313-317, https://doi.org/10.1016/S0009-2541(96)00133-7, 1997.

Loader, N. J., Robertson, I., and McCarroll, D.: Comparison of stable carbon isotope ratios in the whole wood, cellulose and lignin of oak tree-rings, Palaeogeogr. Palaeoclimatol. Palaeoecol., 196, 395-407, https://doi.org/10.1016/S0031-0182(03)00466-8, 2003.

Loader, N. J., Young, G. H., McCarroll, D., and Wilson, R. J.: Quantifying uncertainty in isotope dendroclimatology, The Holocene, 23, 1221-1226, https://doi.org/10.1177/0959683613486945, 2013.

Loader, N. J., Street-Perrott, F. A., Daley, T. J., Hughes, P. D. M., Kimak, A., Levanič, T., Mallon, G., Mauquoy, D., Robertson, I., Roland, T. P., van Bellen, S., Ziehmer, M. M., and Leuenberger, M.: Simultaneous Determination of Stable Carbon, Oxygen, and Hydrogen Isotopes in Cellulose, Anal. Chem., 87, 376380, https://doi.org/10.1021/ac502557x, 2015.

Mann, M. E., Bradley, R. S., and Hughes, M. K.: Global-scale temperature patterns and climate forcing over the past six centuries, Nature, 392, 779-787, https://doi.org/10.1038/nature02478, 1998.

McCarroll, D. and Loader, N. J.: Stable isotopes in tree rings, in Quaternary Sci. Rev., 23, 771-801, Elsevier, 2004.

Nicolussi, K. and Patzelt, G.: Discovery of early-Holocene wood and peat on the forefield of the Pasterze Glacier, Eastern Alps, Austria, The Holocene, 10, 191-199, https://doi.org/10.1191/095968300666855842, 2000a.

Nicolussi, K. and Patzelt, G.: Untersuchungen zur holozänen Gletscherentwicklung von Pasterze und Gepatschferner (Ostalpen), Zeitschrift für Gletscherkd. und Glazialgeol., 36, 1-87, 2000b.

Nicolussi, K. and Schlüchter, C.: The 8.2 ka event-Calendardated glacier response in the Alps, Geology, 40, 819-822, https://doi.org/10.1130/G32406.1, 2012.

Nicolussi, K., Kaufmann, M., Patzelt, G., Plicht Van Der, J., and Thurner, A.: Holocene tree-line variability in the Kauner Valley, Central Eastern Alps, indicated by dendrochronological analysis of living trees and subfossil logs, Veg. Hist. Archaeobot., 14, 221-234, https://doi.org/10.1007/s00334-005-0013-y, 2005.
Nicolussi, K., Kaufmann, M., Melvin, T. M., van der Plicht, J., Schiessling, P., and Thurner, A.: A 9,111 year long conifer treering chronology for the European Alps: a base for environmental and climatic investigations, The Holocene, 19, 909-920, https://doi.org/10.1177/0959683609336565, 2009.

Rebetez, M. and Reinhard, M.: Monthly air temperature trends in Switzerland 1901-2000 and 1975-2004, Theor. Appl. Climatol., 91, 27-34, https://doi.org/10.1007/s00704-007-0296-2, 2008.

Rinn, F.: Tsap V 3.6 Reference manual: computer program for treering analysis and presentation, Rinntech, Heidelb., 1996.

Schleser, G. H., Frielingsdorf, J., and Blair, A.: Carbon isotope behaviour in wood and cellulose during artificial aging, Chem. Geol., 158, 121-130, https://doi.org/10.1016/S00092541(99)00024-8, 1999.

Tranquilini, W.: Physiological Ecology of the Alpine Timberline, Ecol. Stu., Vol. 31, Springer-Verlag, Berlin, 1979.

Treydte, K., Frank, D., Esper, J., Andreu, L., Bednarz, Z., Berninger, F., Boettger, T., D’Alessandro, C. M., Etien, N., Filot, M., Grabner, M., Guillemin, M. T., Gutierrez, E., Haupt, M., Helle, G., Hilasvuori, E., Jungner, H., Kalela-Brundin, M., Krapiec, M., Leuenberger, M., Loader, N. J., Masson-Delmotte, V., Pazdur, A., Pawelczyk, S., Pierre, M., Planells, O., Pukiene, R., Reynolds-Henne, C. E., Rinne, K. T., Saracino, A., Saurer, M., Sonninen, E., Stievenard, M., Switsur, V. R., Szczepanek, M., Szychowska-Krapiec, E., Todaro, L., Waterhouse, J. S., Weigl, M., and Schleser, G. H.: Signal strength and climate calibration of a European tree-ring isotope network, Geophys. Res. Lett., 34, L24302, https://doi.org/10.1029/2007GL031106, 2007.

Treydte, K. S., Schleser, G. H., Helle, G., Frank, D. C., Winiger, M., Haug, G. H., and Esper, J.: The twentieth century was the wettest period in northern Pakistan over the past millennium, Nature, 440, 1179-1182, https://doi.org/10.1038/nature04743, 2006.

Trouet, V., Esper, J., Graham, N. E., Baker, A., Scourse, J. D., and Frank, D. C.: Persistent positive North Atlantic oscillation mode dominated the Medieval Climate Anomaly, Science, 324, 78-80, https://doi.org/10.1126/science.1166349, 2009.

Tukey, J. W.: Exploratory Data Analysis, Addison-Wesley Publishing Company, 1977.

Wanner, H., Solomina, O., Grosjean, M., Ritz, S. P., and Jetel, M.: Structure and origin of Holocene cold events, Quaternary Sci. Rev., 30, 3109-3123, https://doi.org/10.1016/j.quascirev.2011.07.010, 2011.

Wanner, H., Mercolli, L., Grosjean, M., and Ritz, S. P.: Holocene climate variability and change; a data-based review, J. Geol. Soc. London., 172, 254-263, https://doi.org/10.1144/jgs2013101, 2015.

Ziehmer, M. M., Nicolussi, K., Schlüchter, C., and Leuenberger, M.: Tree-species and site sensitivity of two high-Alpine tree species in the Swiss Alps, in preparation, 2018. 